\title{
Seasonal dynamics of methane emissions from a subarctic fen in the Hudson Bay Lowlands
}

\author{
K. L. Hanis ${ }^{1}$, M. Tenuta ${ }^{1}$, B. D. Amiro ${ }^{1}$, and T. N. Papakyriakou ${ }^{2}$ \\ ${ }^{1}$ Department Soil Science, University of Manitoba, Winnipeg, Manitoba, Canada \\ ${ }^{2}$ Department Environment and Geography, University of Manitoba, Winnipeg Manitoba, Canada
}

Correspondence to: M. Tenuta (mario.tenuta@ad.umanitoba.ca)

Received: 15 February 2013 - Published in Biogeosciences Discuss.: 8 March 2013

Revised: 31 May 2013 - Accepted: 3 June 2013 - Published: 3 July 2013

\begin{abstract}
Ecosystem-scale methane $\left(\mathrm{CH}_{4}\right)$ flux $\left(\mathrm{F}_{\mathrm{CH}_{4}}\right)$ over a subarctic fen at Churchill, Manitoba, Canada was measured to understand the magnitude of emissions during spring and fall shoulder seasons, and the growing season in relation to physical and biological conditions. $F_{\mathrm{CH}_{4}}$ was measured using eddy covariance with a closed-path analyser in four years (2008-2011). Cumulative measured annual $\mathrm{F}_{\mathrm{CH}_{4}}$ (shoulder plus growing seasons) ranged from 3.0 to $9.6 \mathrm{~g} \mathrm{CH}_{4} \mathrm{~m}^{-2} \mathrm{yr}^{-1}$ among the four study years, with a mean of 6.5 to $7.1 \mathrm{~g} \mathrm{CH}_{4} \mathrm{~m}^{-2} \mathrm{yr}^{-1}$ depending upon gap-filling method. Soil temperatures to depths of $50 \mathrm{~cm}$ and air temperature were highly correlated with $\mathrm{F}_{\mathrm{CH}_{4}}$, with near-surface soil temperature at $5 \mathrm{~cm}$ most correlated across spring, fall, and the shoulder and growing seasons. The response of $\mathrm{F}_{\mathrm{CH}_{4}}$ to soil temperature at the $5 \mathrm{~cm}$ depth and air temperature was more than double in spring to that of fall. Emission episodes were generally not observed during spring thaw. Growing season emissions also depended upon soil and air temperatures but the water table also exerted influence, with $F_{\mathrm{CH}_{4}}$ highest when water was $2-13 \mathrm{~cm}$ below and lowest when it was at or above the mean peat surface.
\end{abstract}

\section{Introduction}

Organic soils (peatlands) have the highest mean soil organic carbon contents of any permafrost-affected soil in the northern circumpolar permafrost region with global inventories of 94 to $184 \mathrm{Pg}$ carbon in the top $3 \mathrm{~m}$ (Tarnocai et al., 2009). Terrestrial regions of the Arctic, including peatlands, are estimated to have sequestered between 300 and $600 \mathrm{Tg} \mathrm{C} \mathrm{yr}^{-1}$ since 1975 (McGuire et al., 2009). However, the radiative forcing benefit of a carbon dioxide $\left(\mathrm{CO}_{2}\right)$ sink is partially offset by the emission of 30 to $100 \mathrm{Tg} \mathrm{yr}^{-1}$ methane $\left(\mathrm{CH}_{4}\right)$ from the terrestrial arctic (McGuire et al., 2009), of which 2.3 $\mathrm{Tg} \mathrm{CH}_{4} \mathrm{yr}^{-1}$ are emitted from the Hudson Bay Lowlands in Canada (Pickett-Heaps et al., 2011). This is important because $\mathrm{CH}_{4}$ has a radiative forcing of about 33 times that of $\mathrm{CO}_{2}$ over $100 \mathrm{yr}$ when including the direct and indirect radiative effects of aerosol responses (Shindell et al., 2009), and 25 times that of $\mathrm{CO}_{2}$ directly (Forster et al., 2007).

Previous studies of $\mathrm{CH}_{4}$ fluxes $\left(\mathrm{F}_{\mathrm{CH}_{4}}\right)$ from northern peatlands have focussed on the period of peak productivity of vegetation (mid-summer) (e.g. Verville et al., 1998; Updegraff et al., 2001; Grondahl et al., 2008) and examined the effects of water table height (e.g. Turetsky et al., 2008; Long et al., 2009; Zona et al., 2009), temperature (e.g. Verville et al., 1998; Wille et al., 2008; Long et al., 2009), and plant communities, in particular, hydrophytes with aerenchyma tissues for plant-mediated transport of rhizosphere gases to the atmosphere (e.g. Schimel, 1995; Long et al., 2009) on emissions. It has been found that photosynthetically active radiation and net ecosystem exchange of $\mathrm{CO}_{2}$ can be used to encompass the effect of light intensity on plant photosynthetic activity and transpiration as well as plant mediated transport fluxes of rhizosphere gases such as $\mathrm{CH}_{4}$ (Joabsson et al., 1999). Consequently, an understanding of growing season $\mathrm{F}_{\mathrm{CH}_{4}}$ and associated drivers is being developed; however, more research is needed to understand fluxes outside of the main growing season. Little is known about $\mathrm{F}_{\mathrm{CH}_{4}}$ during the shoulder periods of spring melt and fall freeze-up. Shoulder periods may be important to understand the conditions driving the transition in emission to and from shoulder periods and the growing season. 
Recent attention has focused on $\mathrm{CH}_{4}$ emission bursts during the spring and fall seasons from northern peatlands. Tokida et al. (2007) described episodic release of $\mathrm{CH}_{4}$ from bubbles in ice overlying an ombrotrophic bog in Japan during spring melt, and Hargreaves et al. (2001) reported springmelt $F_{\mathrm{CH}_{4}}$ bursts from a Finnish minerotrophic flark fen dominated by graminoids. Fall freeze-up $F_{\mathrm{CH}_{4}}$ bursts have also been reported to occur during freeze-thaw cycles in the same Finnish flark fen (Hargreaves et al., 2001) and in a graminoid fen in Greenland underlain by permafrost (Mastepanov et al., 2008).

Emission bursts could contribute substantially to annual $F_{\mathrm{CH}_{4}}$, but they are ephemeral and spatially variable, and the drivers are still not clearly understood. More research is needed at northern circumpolar peatlands during the shoulder seasons of spring melt and fall freeze-up to focus on understanding the trends and magnitude of $\mathrm{F}_{\mathrm{CH}_{4}}$ and the associated drivers of emissions over different spatial and temporal scales.

The objectives of this study were to determine ecosystem scale $F_{\mathrm{CH}_{4}}$ from an eutrophic subarctic fen to understand (a) the magnitude of emissions during spring-melt and fallfreeze-up periods relative to the growing season, and (b) the environmental conditions contributing to emissions. We hypothesized that $F_{\mathrm{CH}_{4}}$ is a well-behaved function of temperature given favourable water table conditions in peatlands. We tested this through campaign measurements of wholeecosystem $F_{\mathrm{CH}_{4}}$ using an eddy-covariance (EC) flux tower during spring and fall campaigns and for four growing seasons from 2008 to 2011.

\section{Methods}

\subsection{Site description}

The study site is a eutrophic palsa fen (fen) (NWWG, 1997) near Churchill, Manitoba, Canada $\left(58^{\circ} 39^{\prime} 57^{\prime \prime} \mathrm{N}\right.$, $93^{\circ} 49^{\prime} 48^{\prime \prime} \mathrm{W}$ ). It is situated within the boreal forest-tundra ecotone, which is a transitional zone extending approximately $10 \mathrm{~km}$ inland from the Hudson Bay coastline, and within the zone of continuous permafrost (Brown, 1970). The fen hosts three dominant landscape units: hummocks, sedge lawns, and hollows. The hummocks and sedge lawns have 30 to $40 \mathrm{~cm}$ of peat over carbonate-rich glaciomarine sediments (Rouse et al., 2002). The active layer can extend to more than $1.5 \mathrm{~m}$ in depth.

The sedge-lawn landscape unit is the most extensive, covering approximately $55 \%$ of the fen (Raddatz et al., 2009) and is dominated by the sedge Carex aquatilis Wahlenb., as well as other Carex spp., the grasses Eriophorum spp., Calamagrostis spp., and Arctagrostis latifolia (R. Br.) Griseb., rushes Juncus spp., horsetail Equisetum variegatum Schleich. ex F. Weber \& D. Mohr, and an understory of the moss, Pseudocalliergon turgescens (Jensen) Loeske. The sedge- lawn landscape unit is at the mean water table-peat surface interface at an elevation of $16.56 \pm 0.4 \mathrm{~m}$ (SD (standard deviation), $n=29$ sample points) with the $P$. turgescens being submersed during periods of a high water table (often June, September and October), and exposed during periods of a low water table (often July and August). C. aquatilis is the principal vascular plant at the fen and can facilitate $\mathrm{CH}_{4}$ transport to the atmosphere (Schimel, 1995). New shoots emerge from mid- to late June; flowering occurs in mid-July and senescence begins in late August.

The vegetation of hummocks is dominated by the lichens Cladina stellaris (Opiz) Brodo and Cladonia rangiferina (L.) Nyl., the moss Dicranum elongatum Schwaegr., as well as heath vegetation Betula glandulosa Michx., Salix arctophila Cock. ex Heller, Rhododendron tomentosum Harmaja, Andromeda polifolia L., Rhododendron lapponicum (L.) Wahlenb., Vaccinium vitis-idaea L. ssp. minus (Lodd.) Hultén, and $V$. uliginosum L. The hummocks are drier mounds that rise above the level of the sedge-peat surface by about $40 \mathrm{~cm}$. The hollows were about $55 \mathrm{~cm}$ below the sedge-peat surface with mats of $P$. turgescens, and partially decomposed peat material at their base, overlying a mineral substrate. They typically were filled with water, except during extreme drought periods.

The water table for the fen fluctuates throughout the growing season, with a typical annual variation of $15 \mathrm{~cm}$ below to $20 \mathrm{~cm}$ above the mean sedge-peat elevation. The maximum water table height usually occurs just after spring snowmelt as the result of the top-down melting of the fen, with water overlying ice at the peat surface. Snowmelt occurred from 23-26 May (day of year (DOY) 144-147) 2008, 11-13 June (DOY 162-164) 2009, 9-14 May (DOY 129-134) 2010 and 30 May-4 June (DOY 150-155) 2011. The fen was snow and ice covered by 26, 13 and 30 October (DOY 300, 286, 303) in 2008, 2009 and 2010 respectively, but ice covered on 23 October (DOY 296) and snow covered on 7 November (DOY 311) 2011 (Table 1).

\subsection{Eddy-covariance flux station}

An eddy-covariance flux tower was established in June of 2008 to measure $F_{\mathrm{CH}_{4}}$ and net ecosystem exchange (NEE). The station was off-grid, powered by wind (Model 200 Whisper Wind Generator, Southwest Windpower Inc., Flagstaff, AZ), solar (five photovoltaic panels for $500 \mathrm{~W}$ combined), and gas power generation (EU2000i, Honda Inc. as supplemental).

The $\mathrm{CH}_{4}$ concentration in atmosphere was measured using a closed-path analyser (RMT-200 Fast Methane Analyzer; Los Gatos Research Inc., Mountain View, CA) (Baer et al., 2002; Hendriks et al., 2008; Baldocchi et al., 2011). The RMT-200 measurement range was 0.1 to $25 \mathrm{ppmv}$ with $<1 \%$ uncertainty (Los Gatos Research, 2009). Methane concentrations were sampled at $10 \mathrm{~Hz}$ and the pressure in the cavity was maintained at $18.998 \mathrm{kPa}$. Air was drawn 
Table 1. Summary table of monthly mean air temperature $\left(T_{\text {air }}\right)$ and total precipitation compared to the 1971-2000 climate normals for Churchill, Manitoba, obtained from Environment Canada, onset date of melt and freeze-up, duration of non-frozen period and measurement period duration and \% coverage. - represents no data available; * represents $312 \mathrm{~mm}$ precipitation for June to November for use in 2009 and 2011 comparisons.

\begin{tabular}{|c|c|c|c|c|c|c|c|c|c|c|c|c|c|}
\hline & May & Jun & Jul & Aug & Sep & Oct & Nov & $\begin{array}{r}\text { Season } \\
\text { Total }\end{array}$ & $\begin{array}{r}\text { Melt } \\
\text { (DOY) }\end{array}$ & $\begin{array}{r}\text { Freeze- } \\
\text { up } \\
(\mathrm{DOY})\end{array}$ & $\begin{array}{l}\text { Non- } \\
\text { Frozen } \\
\text { Period } \\
\text { (days) }\end{array}$ & $\begin{array}{r}\text { Measurement } \\
\text { Period } \\
\text { (DOY-DOY) }\end{array}$ & $\begin{array}{r}\text { Measurement } \\
\text { Period } \\
\text { Coverage }(\%)\end{array}$ \\
\hline \multicolumn{14}{|c|}{ Mean $T_{\text {air }}\left({ }^{\circ} \mathrm{C}\right)$} \\
\hline 2008 & -0.5 & 7.3 & 12.5 & 13.8 & 5.2 & 1.5 & -9.3 & 4.4 & 144 & 300 & 156 & $181-292$ & 12 \\
\hline 2009 & -6.9 & 3.3 & 8.6 & 10.5 & 8.9 & -0.3 & -7.3 & 2.4 & 162 & 286 & 124 & $154-263$ & 27 \\
\hline 2010 & -1.1 & 7.7 & 14.0 & 11.1 & 6.8 & 1.7 & -8.1 & 4.6 & 129 & 303 & 174 & $195-312$ & 32 \\
\hline 2011 & -2.2 & 7.7 & 14.2 & 13.0 & 10.3 & 1.7 & -9.3 & 5.1 & 150 & 296 & 146 & $190-312$ & 65 \\
\hline Normal \# & -0.7 & 6.6 & 12.0 & 11.7 & 5.6 & -1.7 & -12.6 & 3.0 & & & & & \\
\hline \multicolumn{14}{|c|}{ Precipitation (mm) } \\
\hline $2008^{1}$ & 21 & 43.0 & 20.1 & 81.5 & 53.0 & 50.4 & 7.0 & 276.0 & & & & & \\
\hline 2009 & - & 45.9 & 91.5 & 21.6 & 65.3 & 25.4 & 14.4 & 264.1 & & & & & \\
\hline 2010 & 40.9 & 12.5 & 71.9 & 181.4 & 54.2 & 27.2 & 6.9 & 395.0 & & & & & \\
\hline 2011 & - & 42.9 & 59.8 & 80.2 & 24.2 & 102.0 & 12.8 & 321.9 & & & & & \\
\hline Normal \# & 31.9 & 44.3 & 56.0 & 68.3 & 63.4 & 46.9 & 33.1 & 343.9* & & & & & \\
\hline
\end{tabular}

from $4.27 \mathrm{~m}$ above the fen surface to the analyser through a mesh screen (Cole Parmer, Vernon Hills, IL) and $7 \mu \mathrm{m}$ inline filter (Swagelok, Solon, $\mathrm{OH}$ ), and $18 \mathrm{~m}$ of PTFE-Teflon tubing (6.35 mm id (inner diameter); Zeus Inc., Orangeburg, SC). An XDS 35i dry vacuum scroll pump (Edwards, Crawley, West Sussex, UK) drew the air stream at a flow rate of $28.5 \mathrm{~L} \mathrm{~min}^{-1}$ during the 2008 field season with a sample lag of $1.2 \mathrm{~s}$. In 2009, this scroll pump failed and was replaced with two diaphragm vacuum pumps connected in parallel (LABOPORT N840.3, KNF Neuberger, Inc., Trenton, NJ) at a combined flow of $4.6 \mathrm{~L} \mathrm{~min}^{-1}$ and a calculated lag of $7.5 \mathrm{~s}$. This replacement of the high-flow pump with a more reliable lower-flow pump was also done by Detto et al. (2011) at their site. For us, the lower power draw was an added advantage of the slower pumps.

A 3-dimensional ultrasonic anemometer-thermometer (CSAT3, Campbell Scientific Inc., Logan, UT) was centremounted at the same height as the gas sample inlet facing north to measure wind velocities and air temperature. Additionally, an open-path $\mathrm{CO}_{2} / \mathrm{H}_{2} \mathrm{O}$ analyser (LI-7500, LI-COR Biosci., Lincoln, NE), centre-mounted at a $35^{\circ}$ angle facing north at the same height of the gas sample inlet and wind anemometer, was used to determine $\mathrm{CO}_{2}$ and water vapour molar densities. Data were recorded at $10 \mathrm{~Hz}$ by a CR3000 data logger (Campbell Scientific Inc.).

Wind velocities, $\mathrm{CO}_{2}$ and $\mathrm{H}_{2} \mathrm{O}$ densities were recorded nearly continuously. However, due to power generation and storage constraints, the $\mathrm{CH}_{4}$ analyser and pumps could only operate for campaign periods of 2 to $24 \mathrm{~h}$ before the battery storage bank was depleted for the 2008, 2009 and 2010 field seasons. In order to compensate for the power limitations and still capture diurnal trends in $F_{\mathrm{CH}_{4}}$ during the 2011 field season, a relay turned the pumps on for $37 \mathrm{~min}$ to capture a 30 min campaign ( 5 extra minutes prior to and 2 min after the half hour) starting at 00:00, 03:00, 09:00, 11:00, 15:00, 16:00, 17:00 and 21:00 LT (local time). We recognize that there are gaps in our flux measurements where an ephemeral release could have been missed.

\subsection{Supporting environmental variables}

Air temperature $\left(T_{\text {air }}\right)$ was measured at a height of $1.8 \mathrm{~m}$ (HMP45C, Vaisala Inc., Woburn, MA), horizontal wind speed $(u)$ and direction at $4 \mathrm{~m}$ (Model 05103, R.M. Young Co., Traverse City, MI), photosynthetically active radiation (PAR) at $1 \mathrm{~m}$ (PAR Lite sensor, Kipp \& Zonen, Bohemia, $\mathrm{NY}$ ), and rainfall at $0.5 \mathrm{~m}$ (TR-525M, Texas Electronics Inc., Dallas, TX). Soil temperature was measured using thermocouples in two wood dowels at 10, 20,30, 40, 50, and $60 \mathrm{~cm}$ depths, placed in a sedge lawn $\left(T_{\text {sed10 }}, T_{\text {sed20 }}, T_{\text {sed30 }}\right.$, $T_{\text {sed40 }}, T_{\text {sed50 }}$, and $\left.T_{\text {sed60 }}\right)$ and a hollow $\left(T_{\text {hol10 }}, T_{\text {hol20 }}, T_{\text {hol30 }}\right.$, $T_{\text {hol40 }}, T_{\text {hol50 }}$, and $\left.T_{\text {hol60 }}\right)$. Three-junction averaging thermocouples were also placed at $5 \mathrm{~cm}$ depth in three hummocks, sedge lawns and hollows to provide an average near-surface temperature $\left(T_{\text {soil5 }}\right)$. Environmental variables were recorded half hourly using data loggers (CR5000, CR1000, CR23X, Campbell Scientific Inc.). Water table height was read daily from stationary rulers in three hollows during all four field seasons, and recorded half hourly by three pressure transducers (HOBO U20 Water Level Data Loggers, Onset Computer Corporation, Inc., Pocasset, MA) in the 2011 field season. Elevation of ruler tops and the sedge-peat surface (29 locations) were determined by GPS (TSC1 Asset Surveyor, Trimble Navigation Ltd., Sunnyvale, CA).

\subsection{Data analysis}

Half-hourly EC fluxes were calculated using MATLAB (R2007a, The Math Works Inc., Natick, MA) user-defined 
functions. Spikes in the measured high-frequency data were removed based on thresholds for each signal set to identify single spurious values. Block-average covariances were calculated without detrending and then coordinate rotated for each 30 min period (Tanner and Thurtell, 1969). The covariances were maximized half hourly by adjusting lag delays. High-frequency losses of the closed-path $\mathrm{CH}_{4}$ analyser were calculated by comparing the fractional loss of energy in the $F_{\mathrm{CH}_{4}}$ spectrum to the spectrum for sensible heat flux. This resulted in a correction of $1.5 \%$ for the high-volume pump in 2008 and $12 \%$ for the low-volume pump in the other years. Density effects were corrected for water vapour for the closed-path $\mathrm{CH}_{4}$ system, and for both heat and water vapour for the open-path $\mathrm{CO}_{2}$ system (Webb et al., 1980). Self-heating of the LI-7500 analyser was included based on the corrections of Burba et al. (2008).

$F_{\mathrm{CH}_{4}}$ data from the $\mathrm{CH}_{4}$ analyser were filtered to omit values when only one of the two diaphragm pumps was running, the mirror ring-down value had declined more than $20 \%$, or when the internal pressure became $<17.998 \mathrm{kPa}$. NEE data were filtered when rain and particles intercepted the sensor path based on the analyser's diagnostic report. All $F_{\mathrm{CH}_{4}}$ determinations were filtered to remove half-hour periods at night (PAR $<10 \mu \mathrm{mol} \mathrm{m}^{-2} \mathrm{~s}^{-1}$ ) when the friction velocity $\left(u^{*}\right)$ was below a threshold of $0.2 \mathrm{~m} \mathrm{~s}^{-1}$ ( $u_{\text {threshold }}^{*}$ ). NEE data were restricted to midday values from 11:00 to 15:00 LT (NEE $\mathrm{ND}_{\mathrm{D}}$ ), when plant productivity would be highest. $F_{\mathrm{CH}_{4}}$ and $\mathrm{NEE}_{\mathrm{MD}}$ data were filtered to remove half-hourly periods when the cardinal wind direction was $135-225^{\circ}$ to exclude directions from the tower and gas power generator. Upward fluxes are defined as positive.

To observe seasonal trends and determine environmental drivers of $F_{\mathrm{CH}_{4}}$ during the shoulder periods of spring and fall, as well as the growing season, the data was divided into different periods: spring of 2009 (DOY 150-190, 2009), all springs (DOY 150-190, 2008-2011), fall of 2011 (DOY 260-320, 2011), all falls (DOY 260-320, 2008-2011), and all shoulder + growing seasons (DOY 150-320, 2008-2011).

Pearson's product-moment correlation analysis was performed on all half-hourly $F_{\mathrm{CH}_{4}}$ data and $T_{\text {air }}, T_{\text {soil5 }}, T_{\text {sed10, }}$, $T_{\text {sed20 }}, T_{\text {sed50 }}, T_{\text {hol10 }}, T_{\text {hol20 }}, T_{\text {hol50 }}, \mathrm{NEE}_{\mathrm{MD}}$, water table and PAR with $P<0.0001$ set as significant. Correlations were done to show relationships for spring of 2009, all springs, fall of 2011, all falls, and all shoulder + growing seasons. Visual inspection of relations between $F_{\mathrm{CH}_{4}}$ and environmental variables indicated linear rather than exponential functions. The strength of the Pearson's product-moment correlation was graded on a scale: strong correlation when $R \geq \pm 0.80$, moderate correlation when $\pm 0.79 \geq R \geq \pm 0.50$, and weak correlation when $R \leq \pm 0.49$.

Temperature response of $F_{\mathrm{CH}_{4}}$ was determined using linear regression analysis for $1{ }^{\circ} \mathrm{C}$ bin-averaged $30 \mathrm{~min} F_{\mathrm{CH}_{4}}$ data for all springs, all falls and all shoulder + growing seasons using both $T_{\text {air }}$ and $T_{\text {soil5. }}$. The water table response of $F_{\mathrm{CH}_{4}}$ was determined using linear regression analysis for $1 \mathrm{~cm}$-height bin-averaged $30 \mathrm{~min} F_{\mathrm{CH}_{4}}$ for the same time periods. The strength of the linear relationship between $F_{\mathrm{CH}_{4}}$ and environmental variables was graded on a scale: strong linear relationship when $r^{2} \geq \pm 0.80$, moderate relationship when $\pm 0.79 \geq r^{2} \geq \pm 0.50$, and weak relationship when $r^{2} \leq \pm 0.49$. The slope of the response of $F_{\mathrm{CH}_{4}}$ to a change in temperature $\left(\Delta F_{\mathrm{CH}_{4}}{ }^{\circ} \mathrm{C}^{-1}\right)$ or water table $\left(\Delta F_{\mathrm{CH}_{4}} \mathrm{~m}^{-1}\right)$ was done using Student's $t$ statistic calculated as the difference between slopes divided by the standard error of the difference between slopes at $n-4^{\circ}$ of freedom (Kleinbaum and Kupper, 1978) using SigmaPlot 11.0 (Systat Software, Inc., San Jose, CA).

A multivariate model for methane emissions as a function of the measured variables was developed using stepwise multiple linear regression and SigmaPlot 11.0. The dataset for all periods and years was partitioned based on water table height being above or below $16.61 \mathrm{~m}$ a.s.l. $(5 \mathrm{~cm}$ above the mean sedge-peat surface). Partition was done because $F_{\mathrm{CH}_{4}}$ was non-linear with respect to the water table where fluxes were very low (mean $16 \mathrm{nmol} \mathrm{m}^{-2} \mathrm{~s}^{-1}$ ) when above $16.61 \mathrm{~m}$ a.s.l. Analysis was done using $30 \mathrm{~min}$ mean values for each data partition with an $F=4000(P=0.047)$ and $F=3900(P=0.050)$ for entry and removal of each variable in the model.

Mean daily $F_{\mathrm{CH}_{4}}$ values are reported from the average of 30 min emissions without gap-filling missing periods in a day. Cumulative annual methane emissions were estimated by summing the mean daily fluxes for all days when daily mean air temperature was $\geq 0{ }^{\circ} \mathrm{C}$ by (1) using linear interpolation to gap-fill missing days between mean daily fluxes of measured $30 \mathrm{~min} F_{\mathrm{CH}_{4}}\left(\Sigma F_{\mathrm{CH}_{4}-\mathrm{GF} 1}\right)$, (2) using linear interpolation to fill $30 \mathrm{~min}$ gaps between measured $F_{\mathrm{CH}_{4}}\left(\Sigma F_{\mathrm{CH}_{4}-\mathrm{GF} 2}\right)$, and (3) modelling the missing $30 \mathrm{~min}$ $F_{\mathrm{CH}_{4}}$ values using the $T_{\text {soils }}$ linear regression relationship with $F_{\mathrm{CH}_{4}}$ (for all shoulder + growing seasons) up to $12^{\circ} \mathrm{C}$ $\left(\Sigma F_{\mathrm{CH}_{4}-\mathrm{GF} 3}\right)$. Above this temperature, the flux was assumed constant at $47 \mathrm{nmolCH}_{4} \mathrm{~m}^{-2} \mathrm{~s}^{-1}$ based on our measurements. When daily mean air temperature was consistently $<0{ }^{\circ} \mathrm{C}_{\mathrm{CH}_{4}}$ was assumed constant at $0 \mathrm{nmol} \mathrm{CH}_{4} \mathrm{~m}^{-2} \mathrm{~s}^{-1}$. Gap-filling procedure 2 was used to more fully capture diurnal variation since night-time ( $\mathrm{PAR}<10 \mu \mathrm{mol} \mathrm{m}^{-2} \mathrm{~s}^{-1}$ ) data capture of $\mathrm{F}_{\mathrm{CH}_{4}}$ was $0-4 \%$ of all potential night-time halfhour periods.

\section{Results}

\subsection{Weather conditions}

Monthly mean $T_{\text {air }}$ and total precipitation for the 2008 field season showed that it was warmer than the 1971-2000 climate normals for Churchill, Manitoba (normal; Environment Canada, 2012) for all study months, drier than normal for July and November and wetter than normal in August (Table 1). Seasonally from May to November, $T_{\text {air }}$ was $1.4^{\circ} \mathrm{C}$ 
warmer, and had $67.9 \mathrm{~mm}$ less precipitation than the longterm average.

In 2009, winter air temperatures from January to April were normal (monthly mean temperatures of $-24^{\circ} \mathrm{C}$ to $-21^{\circ} \mathrm{C}$ from January-March and $-8^{\circ} \mathrm{C}$ for April), then cooler and wetter than normal conditions were experienced early in the season from May to July, followed by warmer and drier conditions in the fall from September to November. Seasonal totals indicate that $T_{\text {air }}$ was $0.6^{\circ} \mathrm{C}$ cooler and had $47.9 \mathrm{~mm}$ less precipitation than the long-term average for May to November.

In 2010, conditions were warmer and wetter than normal for July and August, with precipitation in August being $265 \%$ greater than normal. Fall conditions from September to November were warmer and drier than normal. Seasonally, from May to November $T_{\text {air }}$ was $1.6^{\circ} \mathrm{C}$ warmer, and had $51.1 \mathrm{~mm}$ more precipitation than the long-term average.

The 2011 conditions showed that it was warmer than normal in July and throughout the fall from September to November. Drier than normal conditions occurred in September and November, while wetter than normal conditions occurred in October. Seasonal totals indicate that $T_{\text {air }}$ was $2.1^{\circ} \mathrm{C}$ warmer and had $9.9 \mathrm{~mm}$ more precipitation than the long-term average for May to November.

\subsection{Spring $\boldsymbol{F}_{\mathrm{CH}_{4}}$}

We were able to monitor the spring melt of 2009 (Fig. 1). In other years instrument and flux station repairs delayed measurements until after the spring-melt period. The spring of 2009 was categorized into three periods: the snow- and icecovered "pre-melt" (DOY 150 to 161), the transitional "melt" period from snow and ice cover to open water (DOY 162 to 173), and "post-melt" (DOY 174 to 190) when no ice was present above the peat to inhibit $F_{\mathrm{CH}_{4}}$ diffusion.

During the 2009 pre-melt period, $F_{\mathrm{CH}_{4}}$ was near zero ( -6 to $\left.8 \mathrm{nmol} \mathrm{CH}_{4} \mathrm{~m}^{-2} \mathrm{~s}^{-1}\right)$. $T_{\text {air }}$ was mostly below $0{ }^{\circ} \mathrm{C}$ until DOY 158, and temperatures at all soil depths were less than $0^{\circ} \mathrm{C}$. Midday net $\mathrm{CO}_{2}$ flux $\left(\mathrm{NEE}_{\mathrm{MD}}\right)$ ranged from 0 to $2 \mu \mathrm{mol} \mathrm{CO} \mathrm{m}^{-2} \mathrm{~s}^{-1}$.

Throughout the 2009 melt period, $T_{\text {air }}$ was mostly above $0{ }^{\circ} \mathrm{C}$, with daytime highs between 5 and $15^{\circ} \mathrm{C}$. Soil temperatures were less than $0^{\circ} \mathrm{C}$ until DOY 168 when $T_{\text {soil }}>0{ }^{\circ} \mathrm{C}$ but the deeper soil remained frozen. By DOY 167, most of the fen surface thawed and was free of ice and snow and the water table dropped from $22 \mathrm{~cm}$ above the peat surface to $<1 \mathrm{~cm}$ below the surface by DOY 172 . During the melt period $F_{\mathrm{CH}_{4}}$ increased from near zero to $20 \mathrm{nmol} \mathrm{CH}_{4} \mathrm{~m}^{-2} \mathrm{~s}^{-1}$ and $\mathrm{NEE}_{\mathrm{MD}}$ ranged from 1 to $3 \mu \mathrm{mol} \mathrm{CO}_{2} \mathrm{~m}^{-2} \mathrm{~s}^{-1}$.

In the 2009 post-melt period, $F_{\mathrm{CH}_{4}}$ gradually increased to have midday peaks of 40 to $110 \mathrm{nmol} \mathrm{CH}_{4} \mathrm{~m}^{-2} \mathrm{~s}^{-1}$ by DOY 188. A diurnal pattern in $F_{\mathrm{CH}_{4}}$ was evident, and followed $T_{\text {air }}$ and $T_{\text {soil5. }}$. Air temperature remained above $0{ }^{\circ} \mathrm{C}$ throughout the period and daytime highs gradually increased from 10 to $23^{\circ} \mathrm{C} ; T_{\text {soil5 }}$ reached daytime highs of $14{ }^{\circ} \mathrm{C}$ by the end of the

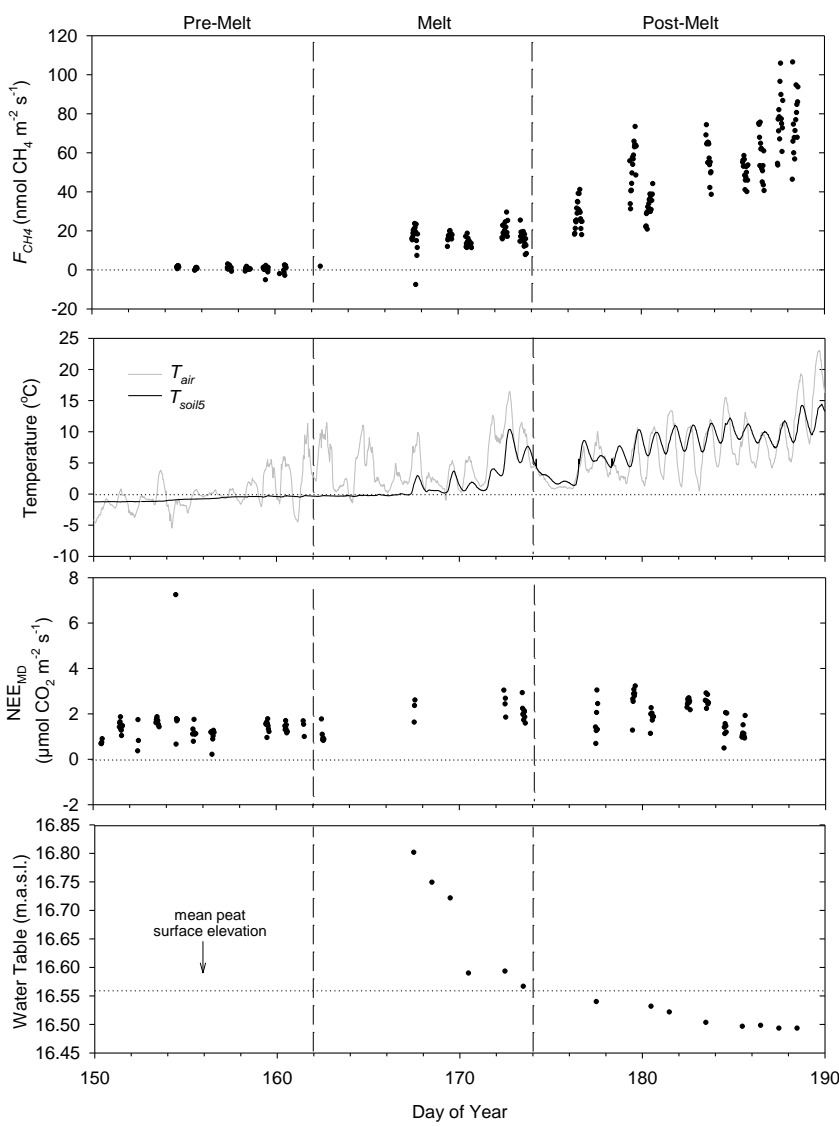

Fig. 1. Spring of $200930 \mathrm{~min} \mathrm{CH}_{4}$ flux $\left(F_{\mathrm{CH}_{4}}\right)$, air temperature $\left(T_{\text {air }}\right), 5 \mathrm{~cm}$ soil temperature $\left(T_{\text {soil5 }}\right)$, midday net $\mathrm{CO}_{2}$ flux $\left(\mathrm{NEE}_{\mathrm{MD}}\right)$ and water table height for the fen from 30 May to 9 July 2009 (DOY 150 to 190 ).

period. The $10 \mathrm{~cm}$ soil depth thawed on DOY 177 and other soil depths remained frozen. The water table gradually lowered to $8 \mathrm{~cm}$ below the peat surface by DOY 188 and NEE emissions ranged from 1 to $3 \mu \mathrm{mol} \mathrm{CO} \mathrm{Cm}^{-2} \mathrm{~s}^{-1}$.

$F_{\mathrm{CH}_{4}}$ during the 2009 post-melt period was similar to $F_{\mathrm{CH}_{4}}$ across all springs (Fig. 2); mean daily $F_{\mathrm{CH}_{4}}$ ranged from 30 to $70 \mathrm{nmol} \mathrm{CH}_{4} \mathrm{~m}^{-2} \mathrm{~s}^{-1}$. Across all springs $T_{\text {soil5 }}$ increased from -1 to $17^{\circ} \mathrm{C}$, with $T_{\text {soils }}$ for spring of 2009 being within range but lowest of all springs. $\mathrm{NEE}_{\mathrm{MD}}$ was dominated by respiration ( 0 to $3 \mu \mathrm{mol} \mathrm{CO} \mathrm{Cm}^{-2} \mathrm{~s}^{-1}$ ) until DOY 180 across all springs. After DOY 180, uptake of $\mathrm{CO}_{2}$ by the plants began to outweigh respiration; with the general trend across all springs showing $\mathrm{NEE}_{\mathrm{MD}}$ transition from 2 to $-2 \mu \mathrm{mol} \mathrm{CO} \mathrm{m}^{-2} \mathrm{~s}^{-1}$ by DOY 190 except for the spring of 2009 which remained respiration dominated until after DOY 190. Early season water table was variable due to the timing of melt ranging from 2 to $12 \mathrm{~cm}$ below the peat surface across all springs. The levels in 2009 were within this range. 


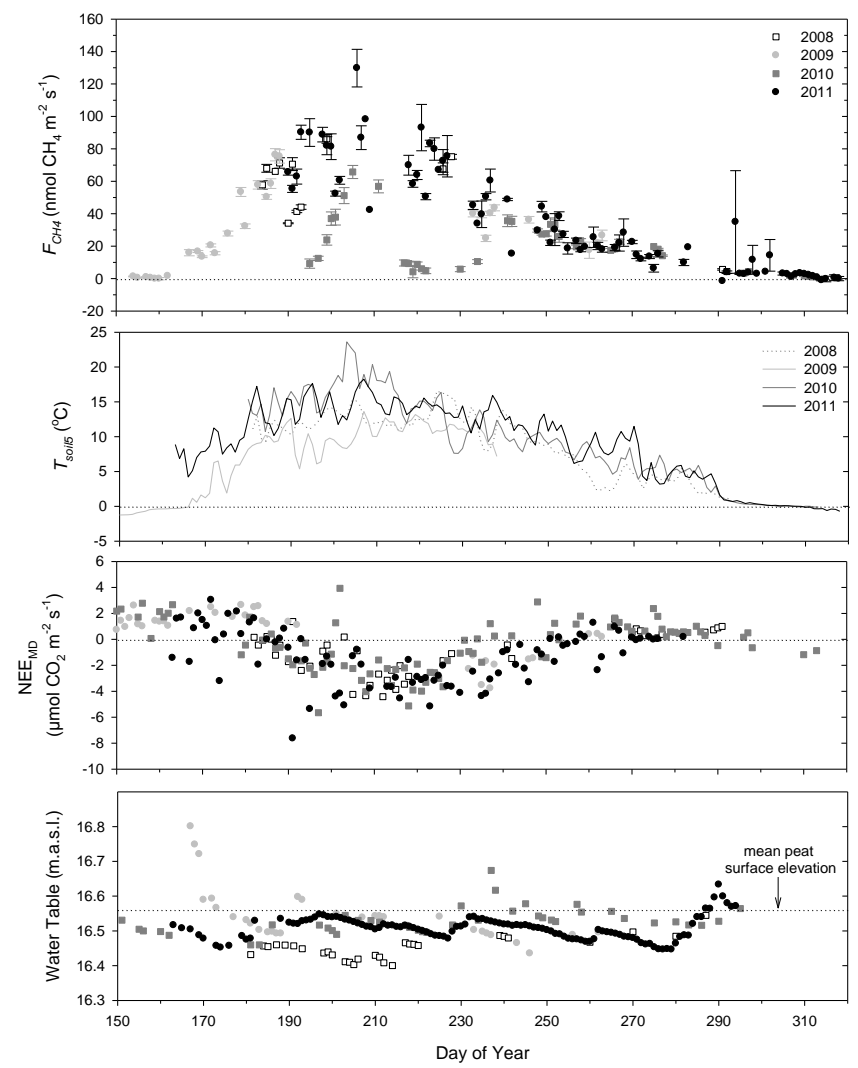

Fig. 2. Mean daily $F_{\mathrm{CH}_{4}}$ (no gap-filling) for $30 \mathrm{~min}$ averaged campaign periods ( $n=1$ to 48$) \pm 1 \mathrm{SE}$ (standard error) shown, and mean daily $T_{\text {soil5 }}, \mathrm{NEE}_{\mathrm{MD}}$ and water table height for all shoulder + growing seasons (DOY 150-320, 2008-2011).

\subsection{Fall $\boldsymbol{F}_{\mathrm{CH}_{4}}$}

The fall of 2011 provided the most extensive coverage of $F_{\mathrm{CH}_{4}}$ due to the power relay automation of the flux station implemented in the 2011 field season, which conserved power (Fig. 3). This was divided into two periods: "prefreeze" with senesced vegetation and mean daily $T_{\text {air }}>0{ }^{\circ} \mathrm{C}$ (DOY 260 to 289), and "freeze-up" when ice formed over standing water at the fen and mean daily $T_{\text {air }}$ and soil temperatures were $\leq 0^{\circ} \mathrm{C}$ by the end of the period (DOY 290 to 320).

During the pre-freeze period $F_{\mathrm{CH}_{4}}$ ranged from 55 to $0 \mathrm{nmol} \mathrm{CH}_{4} \mathrm{~m}^{-2} \mathrm{~s}^{-1}, T_{\text {air }}$ ranged from 20 to $-1^{\circ} \mathrm{C}$ and $T_{\text {soil5 }}$ was between 12 and $2{ }^{\circ} \mathrm{C} . \mathrm{F}_{\mathrm{CH}_{4}}$ gradually declined over the period following the decreasing temperature trend. The water table was 5 to $10 \mathrm{~cm}$ below the peat surface until DOY 286 then increased to $6 \mathrm{~cm}$ above the surface by the end of the period. $\mathrm{NEE}_{\mathrm{MD}}$ ranged from 2 to $-3 \mu \mathrm{mol} \mathrm{CO}_{2} \mathrm{~m}^{-2} \mathrm{~s}^{-1}$.

Freeze-up period surface ice cover developed quickly with a $10^{\circ} \mathrm{C}$ drop in $T_{\text {air }}$ (from 3 to $-7^{\circ} \mathrm{C}$ ) over 3 days (DOY 290-293) then melted and froze again on DOY 294 . The soil temperature profile reversed on DOY 290, after which the surface remained colder than lower depths until convergence
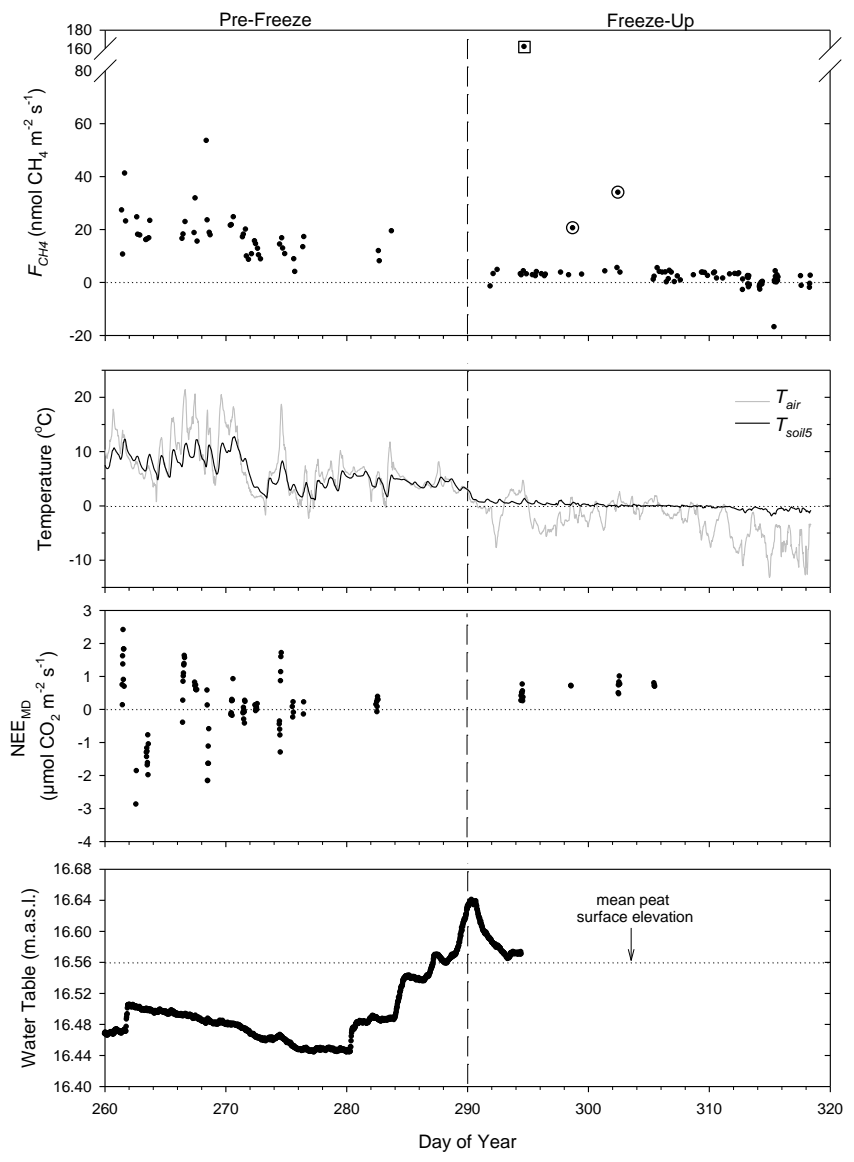

Fig. 3. Fall of $201130 \mathrm{~min} F_{\mathrm{CH}_{4}}, T_{\text {air }}, T_{\text {soil5 }}, \mathrm{NEE}_{\mathrm{MD}}$ and water table height for the fen from 17 September to 16 November 2011 (DOY 260-320). Open square indicates an anthropogenic emission burst, while open circles indicate natural emission bursts.

of $0-60 \mathrm{~cm}$ soil depths to $0^{\circ} \mathrm{C}$ on DOY 317 . By the end of the period, both $T_{\text {air }}$ and $T_{\text {soil5 }}$ were at or below $0{ }^{\circ} \mathrm{C}$. Average over-winter (October-April) soil temperature from 0-60 cm depth was $-2{ }^{\circ} \mathrm{C}$. $\mathrm{NEE}_{\mathrm{MD}}$ emissions ranged from 0 to $1 \mu \mathrm{mol} \mathrm{CO} \mathrm{CO}^{-2} \mathrm{~s}^{-1}$ and the final water table measurement of the season on DOY 294 was $1 \mathrm{~cm}$ above the peat surface. Freeze-up $F_{\mathrm{CH}_{4}}$ was minimal $\left(<6 \mathrm{nmol} \mathrm{CH}_{4} \mathrm{~m}^{-2} \mathrm{~s}^{-1}\right.$ emission) for most of the period, however emission bursts were observed on three occasions. Our visitation of the research site resulted in breaking through surface ice and a $F_{\mathrm{CH}_{4}}$ emission burst on DOY 294 at 17:00 $\left(161 \mathrm{nmol} \mathrm{CH}_{4} \mathrm{~m}^{-2} \mathrm{~s}^{-1}\right.$ over $30 \mathrm{~min}$ period). Two non-disturbance related emission bursts were observed over 30 min periods on DOY 298 at 17:30 where $F_{\mathrm{CH}_{4}}$ was $20 \mathrm{nmolCH}_{4} \mathrm{~m}^{-2} \mathrm{~s}^{-1}$ and on DOY 302 at $11: 30$ where $F_{\mathrm{CH}_{4}}$ was $34 \mathrm{nmol} \mathrm{CH}_{4} \mathrm{~m}^{-2} \mathrm{~s}^{-1}$. In both instances of non-disturbance related emission bursts, wind speed was low ( $\leq 1.4 \mathrm{~m} \mathrm{~s}^{-1}$ ) for two hours leading up to and during the episodes. $T_{\text {air }}$ had been below $0{ }^{\circ} \mathrm{C}$ for 3.5 days then went above $0^{\circ} \mathrm{C}$ for $5.5 \mathrm{~h}$ prior to the emission burst on DOY 298, while $T_{\text {air }}$ had been below $0^{\circ} \mathrm{C}$ for $4 \mathrm{~h}$ and then 


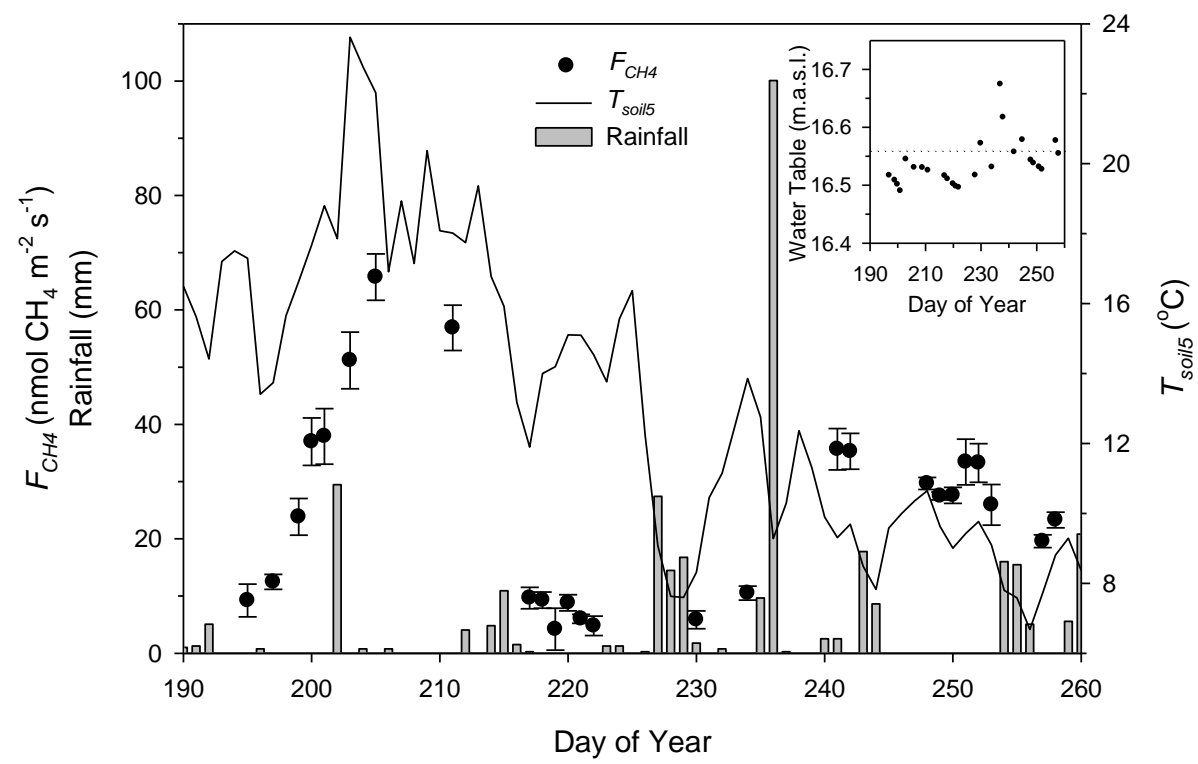

Fig. 4. Growing season mean daily $F_{\mathrm{CH}_{4}}$ (no gap-filling) ( $n=3$ to 42$) \pm 1 \mathrm{SE}$ shown, mean daily $T_{\text {soils }}$ and total daily rainfall for the fen from 9 July to 17 September 2010 (DOY 190-260). Inset Figure: mean daily water table height for the fen 14 from 9 July to 17 September 2010 (DOY 190-260). Dotted line indicates the mean peat surface elevation.

went above $0^{\circ} \mathrm{C}$ for $3 \mathrm{~h}$ before the emission burst on DOY 302. $T_{\text {soils }}$ was at or above $0^{\circ} \mathrm{C}$ before and during both naturally occurring emission burst events.

$F_{\mathrm{CH}_{4}}$ gradually decreased across all falls with mean daily $F_{\mathrm{CH}_{4}}$ declining from 30 to $5 \mathrm{nmolCH}_{4} \mathrm{~m}^{-2} \mathrm{~s}^{-1}$ prior to freeze and from 5 to $-1 \mathrm{nmolCH}_{4} \mathrm{~m}^{-2} \mathrm{~s}^{-1}$ during freezeup (Fig. 2). Fluxes during the fall of 2011 were within the range of those across all falls. $T_{\text {soils }}$ gradually declined from 10 to $-1{ }^{\circ} \mathrm{C}$ with $T_{\text {soils }}$ being coolest in 2008 and warmest in 2011. $\mathrm{NEE}_{\mathrm{MD}}$ became primarily emission again of 0 to $2 \mu \mathrm{mol} \mathrm{CO} \mathrm{Cm}^{-2} \mathrm{~s}^{-1}$ over all falls as $C$. aquatilis senesced and soil respiration outweighed photosynthetic uptake of the plants, however there was still some $\mathrm{CO}_{2}$ uptake during the

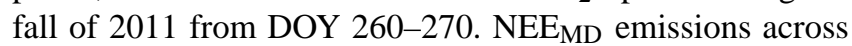
all falls minimized to near zero during freeze-up. From DOY 260 to 290 across all falls, the water table was 1 to $10 \mathrm{~cm}$ below the mean peat surface; then increased precipitation prior to freeze-up raised the water table to 2 to $6 \mathrm{~cm}$ above the mean peat surface. In the fall of 2011, the water table was lower than in other years from DOY 260-280, and was higher than in other years from DOY 289-292.

\subsection{Growing season $\boldsymbol{F}_{\mathrm{CH}_{4}}$}

$F_{\mathrm{CH}_{4}}$ peaked between DOY 190 and 230 with emissions ranging between 30 and $130 \mathrm{nmolCH}_{4} \mathrm{~m}^{-2} \mathrm{~s}^{-1}$ in 2008, 2009 and 2011 (Fig. 2). This peak in emissions occurred during maximum $T_{\text {soil } 5}\left(5\right.$ to $17^{\circ} \mathrm{C}$ ), flowering of C. aquatilis, peak $\mathrm{CO}_{2}$ uptake ( 0 to $-6 \mu \mathrm{mol} \mathrm{CO}_{2} \mathrm{~m}^{-2} \mathrm{~s}^{-1}$ ) by the ecosystem, and water table residing 2 to $15 \mathrm{~cm}$ below the peat surface (Fig. 2).
Growing season $F_{\mathrm{CH}_{4}}$ measurements in 2010 were very different than other growing seasons. In $2010, F_{\mathrm{CH}_{4}}$ was minimal between DOY 190 and 200, with emissions of 10 to $25 \mathrm{nmol} \mathrm{CH}_{4} \mathrm{~m}^{-2} \mathrm{~s}^{-1}$ compared to other years where the range was 30 to $90 \mathrm{nmol} \mathrm{CH}_{4} \mathrm{~m}^{-2} \mathrm{~s}^{-1}$ (Figs. 2, 4). During the same time period in $2010, T_{\text {soils }}$ ranged from 13 to $17{ }^{\circ} \mathrm{C}$ and $\mathrm{NEE}_{\mathrm{MD}}$ uptake ranged from near 0 to $-5 \mu \mathrm{mol} \mathrm{CO} \mathrm{m}^{-2} \mathrm{~s}^{-1}$. The water table was 5 to $6 \mathrm{~cm}$ below the peat surface, and total rainfall was $8 \mathrm{~mm}$ (Fig. 4). The month prior to these measurements was warmer and drier than normal with a mean monthly $T_{\text {air }}$ of $1.1^{\circ} \mathrm{C}$ above the 1971-2000 climate normal, and total monthly precipitation of $32 \mathrm{~mm}$ below the normal (Table 1). The 2010 growing season $F_{\mathrm{CH}_{4}}$ then peaked between 35 and $65 \mathrm{nmol} \mathrm{CH}_{4} \mathrm{~m}^{-2} \mathrm{~s}^{-1}$ for DOY 200 to 210 with increasing $T_{\text {soil5 }}$ and a re-wetting of the soil to create warm anaerobic conditions (Figs. 2, 4). However, $F_{\mathrm{CH}_{4}}$ rapidly declined again to $<12 \mathrm{nmol} \mathrm{CH}_{4} \mathrm{~m}^{-2} \mathrm{~s}^{-1}$ between DOY 220 and 230, coinciding with a dramatic cooling trend of $T_{\text {soils }}$ from 23 to $8^{\circ} \mathrm{C}$. Emissions continued to be suppressed from DOY 230 to 240 with a rapid rise in water table resulting from several multiday rain events. A large rainfall event $(110 \mathrm{~mm}$ in $24 \mathrm{~h})$ on DOY 236 raised the water table $12 \mathrm{~cm}$ above the peat surface (Fig. 4). Coincidentally, $F_{\mathrm{CH}_{4}}$ began to increase as the water table dropped, immediately following this event.

\subsection{Cumulative annual $\mathrm{CH}_{4}$ emissions}

Cumulative annual $\mathrm{CH}_{4}$ emissions varied by study year and with gap-filling method (Table 3). The 2008 study year had the highest cumulative annual $\mathrm{CH}_{4}$ emissions ranging 
Table 2. Pearson's product-moment correlation analysis for 30 min averaged $\mathrm{F}_{\mathrm{CH}_{4}}$ data and environmental variables. Correlations are shown for spring of 2009 (DOY 150-190), all springs (DOY 150-190, 2008-2011), fall of 2011 (DOY 260-320), all falls (DOY 260-320, 20082011) and all shoulder + growing seasons' (DOY 150-320, 2008-2011) data. NS represents $P>0.0001$ (statistically insignificant) and - represents data not available.

\begin{tabular}{|c|c|c|c|c|c|c|c|c|c|c|c|c|}
\hline & & $T_{\text {air }}$ & $T_{\text {soil5 }}$ & $T_{\mathrm{hol10}}$ & $T_{\text {hol20 }}$ & $T_{\text {hol50 }}$ & $T_{\text {sed10 }}$ & $T_{\text {sed20 }}$ & $T_{\text {sed50 }}$ & $\mathrm{NEE}_{\mathrm{MD}}$ & WT & PAR \\
\hline Spring & $R$ & 0.68 & 0.84 & 0.87 & 0.88 & 0.85 & 0.89 & - & 0.70 & 0.53 & -0.66 & -0.27 \\
\hline 2009 & $N$ & 273 & 273 & 273 & 273 & 273 & 273 & 0 & 273 & 59 & 173 & 273 \\
\hline All & $R$ & 0.72 & 0.85 & 0.85 & 0.72 & 0.84 & 0.81 & NS & 0.74 & NS & -0.70 & NS \\
\hline Springs & $N$ & 311 & 311 & 311 & 311 & 311 & 311 & 38 & 311 & 77 & 203 & 311 \\
\hline Fall & $R$ & 0.74 & 0.75 & 0.67 & 0.66 & 0.63 & 0.74 & 0.68 & NS & NS & NS & 0.55 \\
\hline 2011 & $N$ & 86 & 86 & 86 & 86 & 86 & 86 & 86 & 80 & 11 & 46 & 86 \\
\hline All & $R$ & 0.77 & 0.86 & 0.82 & 0.83 & 0.82 & 0.83 & 0.82 & 0.76 & 0.57 & NS & 0.61 \\
\hline Falls & $N$ & 333 & 312 & 312 & 312 & 312 & 312 & 309 & 306 & 61 & 72 & 333 \\
\hline All Shoulder & $R$ & 0.57 & 0.52 & 0.30 & $\mathrm{NS}$ & -0.24 & 0.54 & 0.41 & -0.26 & NS & -0.15 & 0.30 \\
\hline + Growing & $N$ & 1515 & 1455 & 1465 & 1465 & 1404 & 1431 & 1137 & 1459 & 449 & 1021 & 1515 \\
\hline
\end{tabular}

Table 3. Cumulative annual $\mathrm{CH}_{4}$ emissions for all days when daily mean air temperature $\geq 0{ }^{\circ} \mathrm{C}$ gap-filled by (1) using linear interpolation to gap-fill missing days between measured $F_{\mathrm{CH}_{4}}\left(\Sigma F_{\mathrm{CH}_{4}-\mathrm{GF} 1}\right)$, (2) using linear interpolation to fill 30 min gaps between measured $F_{\mathrm{CH}}$

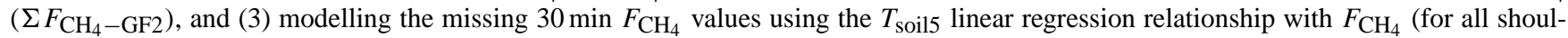
der + growing seasons) up to $12{ }^{\circ} \mathrm{C}$ and above this temperature, the daily flux was assumed constant at $47 \mathrm{nmol} \mathrm{CH}_{4} \mathrm{~m}^{-2} \mathrm{~s}^{-1}\left(\Sigma F_{\mathrm{CH}_{4}}-\mathrm{GF}_{3}\right)$. Mean annual $\mathrm{CH}_{4}$ emissions $\pm 1 \mathrm{SE}$ for the study years 2008-2011 also shown.

\begin{tabular}{llccccc}
\hline & 2008 & 2009 & 2010 & 2011 & Mean $\pm 1 \mathrm{SE}$ \\
\hline$\Sigma F_{\mathrm{CH}_{4}-\mathrm{GF} 1}$ & $\left(\mathrm{~g} \mathrm{CH}_{4} \mathrm{~m}^{-2} \mathrm{yr}^{-1}\right)$ & 9.5 & 6.4 & 4.3 & 8.0 & $7.1 \pm 1.1$ \\
$\Sigma F_{\mathrm{CH}_{4}-\mathrm{GF} 2}$ & $\left(\mathrm{~g} \mathrm{CH}_{4} \mathrm{~m}^{-2} \mathrm{yr}^{-1}\right)$ & 9.6 & 7.6 & 3.0 & 8.0 & $7.0 \pm 1.4$ \\
$\Sigma F_{\mathrm{CH}_{4}-\mathrm{GF} 3}$ & $\left(\mathrm{~g} \mathrm{CH}_{4} \mathrm{~m}^{-2} \mathrm{yr}^{-1}\right)$ & 6.6 & 4.8 & 7.2 & 7.6 & $6.5 \pm 0.6$ \\
\hline
\end{tabular}

from 6.6 to $9.6 \mathrm{~g} \mathrm{CH}_{4} \mathrm{~m}^{-2} \mathrm{yr}^{-1}$, while the 2010 study year had the lowest cumulative annual $\mathrm{CH}_{4}$ emissions ranging from 3.0 to $7.2 \mathrm{~g} \mathrm{CH}_{4} \mathrm{~m}^{-2} \mathrm{yr}^{-1}$. Despite the range in cumulative annual $\mathrm{CH}_{4}$ emissions estimated by the three gapfilling methods on a yearly basis, the means among the three methods were within $9 \%$ of each other when averaged over all four study years (mean $\pm 1 \mathrm{SE}=6.5 \pm 0.6$ to $\left.7.1 \pm 1.1 \mathrm{~g} \mathrm{CH}_{4} \mathrm{~m}^{-2} \mathrm{yr}^{-1}\right)$.

\subsection{Association of $\boldsymbol{F}_{\mathrm{CH}_{4}}$ and environmental variables}

Pearson's product-moment correlation analysis proved temperature to be the strongest driver of $F_{\mathrm{CH}_{4}}$ during spring of 2009 and across all springs (Table 2) where $76 \%$ of the data across all springs was represented by data from spring of 2009. In spring of $2009, T_{\text {air }}$ and soil temperatures to a depth of $50 \mathrm{~cm}$ showed moderate to strong positive correlation $(0.68 \leq R \leq 0.89)$, the water table had a moderate negative correlation with $F_{\mathrm{CH}_{4}}(R=-0.66)$ indicating that as the water table dropped $F_{\mathrm{CH}_{4}}$ increased and NEEMD had a moderate positive correlation with $F_{\mathrm{CH}_{4}}(R=0.53)$. Across all springs, $T_{\text {air }}$ and soil temperatures to a depth of $50 \mathrm{~cm}$ showed moderate to strong positive correlation $(0.72 \leq R \leq 0.85)$; in contrast the water table showed moderate negative correlation $(R=-0.70)$ when compared to spring of 2009. All other variables were not significantly correlated with $F_{\mathrm{CH}_{4}}$ across all springs.

The strongest driver of $F_{\mathrm{CH}_{4}}$ during fall of 2011 and across all falls was soil temperature at $5 \mathrm{~cm}$ depth. In fall of $2011, F_{\mathrm{CH}_{4}}$ had a moderate positive correlation with $T_{\text {soil5 }}$ ( $R=0.75)$ as well as with $T_{\text {air }}$ and all other soil temperatures $(0.63 \leq R \leq 0.74)$ and PAR $(R=0.55)$. All other variables were not significantly correlated with $F_{\mathrm{CH}_{4}}$ for fall of 2011 . Across all falls, $F_{\mathrm{CH}_{4}}$ had a strong positive correlation with $T_{\text {soil5 }}(R=0.86)$ and with $T_{\text {hol10 }}, T_{\text {hol20 }}, T_{\text {hol50 }}, T_{\text {sed10 }}$ and $T_{\text {sed20 }}(R=0.8) . T_{\text {air }}, T_{\text {sed50 }}, \mathrm{NEE}_{\mathrm{MD}}$ and PAR had moderate positive correlations with $F_{\mathrm{CH}_{4}}(0.57 \leq R \leq 0.77)$ across all falls, while all other variables were not significantly correlated with $\mathrm{F}_{\mathrm{CH}_{4}}$.

Over all shoulder + growing seasons, $T_{\text {air }}, T_{\text {soil5 }}$ and $T_{\text {sed10 }}$ had moderate positive correlations $(0.52 \leq R \leq 0.57)$ with $F_{\mathrm{CH}_{4}}$. Other soil temperatures, water table and PAR had weak correlations with $\mathrm{F}_{\mathrm{CH}_{4}}$ and $\mathrm{NEE}_{\mathrm{MD}}$ was not a statistically significant driver of $\mathrm{F}_{\mathrm{CH}_{4}}$.

$F_{\mathrm{CH}_{4}}$ had a strong, positive linear relationship with $T_{\text {soil5, }}$, from 0 to $15^{\circ} \mathrm{C}$, for all springs $\left(r^{2}=0.94\right)$, and from 0 to 

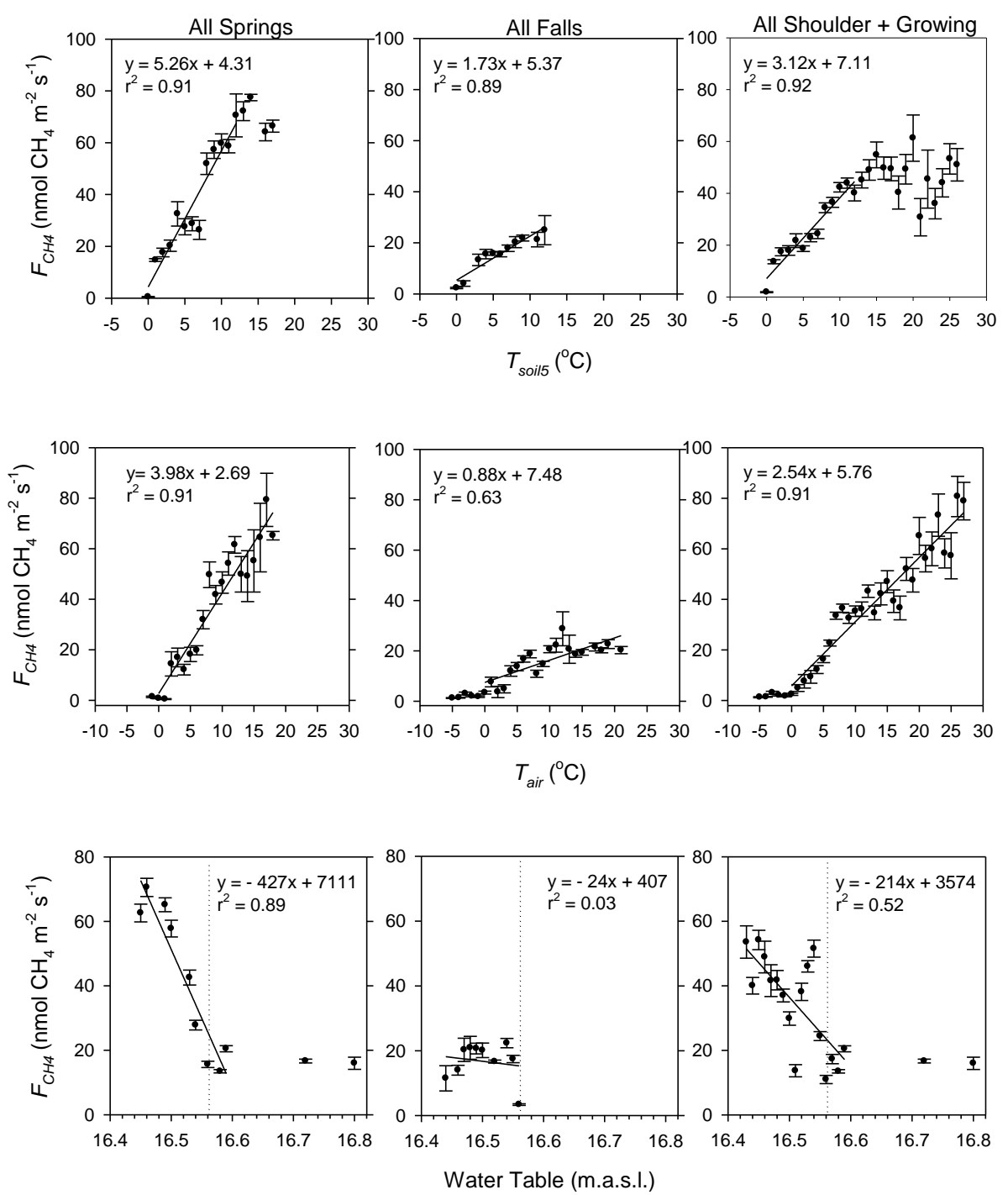

Fig. 5. Bin-averaged $\left(1^{\circ} \mathrm{C}\right) 30 \mathrm{~min} F_{\mathrm{CH}_{4}} \pm 1 \mathrm{SE}$ in response to $T_{\text {soil5 }}$ and $T_{\text {air }}$ shown for all springs (DOY 150 to 190, 2008-2011), all falls (DOY 260 to 320, 2008-2011) and all shoulder + growing seasons (DOY 150-320, 2008-2011). Bin-averaged (1 cm water table height) $30 \mathrm{~min} \mathrm{~F}_{\mathrm{CH}_{4}} \pm 1 \mathrm{SE}$ in response to water table is shown for the same periods. Dotted line indicates the mean peat surface elevation.

$12^{\circ} \mathrm{C}$ for all falls $\left(r^{2}=0.89\right)$ and over all shoulder + growing seasons $\left(r^{2}=0.95\right)$ (Fig. 5). The slope of the linear regression across all springs was more than triple that across all falls and the slopes were significantly different $(P<0.001)$. Positive linear relationships with $T_{\text {air }}$ (from 0 to $30^{\circ} \mathrm{C}$ ) were strong across all springs $\left(r^{2}=0.91\right)$ and across all shoulder + growing seasons $\left(r^{2}=0.91\right)$ and moderate across all falls $\left(r^{2}=0.63\right)$. The slope of the regression across all springs was 4.5 times greater than across all falls and the slopes were significantly different $(P<0.001)$.

$F_{\mathrm{CH}_{4}}$ had a negative linear relationship with the water table from $13 \mathrm{~cm}$ below to $3 \mathrm{~cm}$ above the peat surface, with the strongest relationship for all springs $\left(r^{2}=0.89\right)$. A moderate linear relationship occurred across all shoulder + growing seasons $\left(r^{2}=0.52\right)$, but there was no linear relationship across all falls $\left(r^{2}=0.03\right)$. The slope of the regression across all springs was significantly different $(P<0.001)$ than the slope of the regression for all falls. Over the four study years, the highest $F_{\mathrm{CH}_{4}}$ occurred when the water table was 2 to $15 \mathrm{~cm}$ below the mean peat surface. It was lowest when the water table was at or above the mean peat surface.

The stepwise linear model best predicting 30 min mean $F_{\mathrm{CH}_{4}}$ when water table height was below $16.61 \mathrm{~m}$ a.s.l. $\left(r^{2}=0.76\right)$ was comprised of the variables $T_{\text {hol60 }}$ (partial $\left.r^{2}=0.64\right)$, water table height $\left(r^{2}=0.06\right)$ and $T_{\text {air }}$ $\left(r^{2}=0.06\right)$. When using mean daily values for input values the relation for modelled to measured was linear $(P<0.0001)$ with $r^{2}=0.74$ (Fig. 6). The model over- and under-predicted $F_{\mathrm{CH}_{4}}$ values for the lower and upper ranges of measured values. A model was not possible for the case 


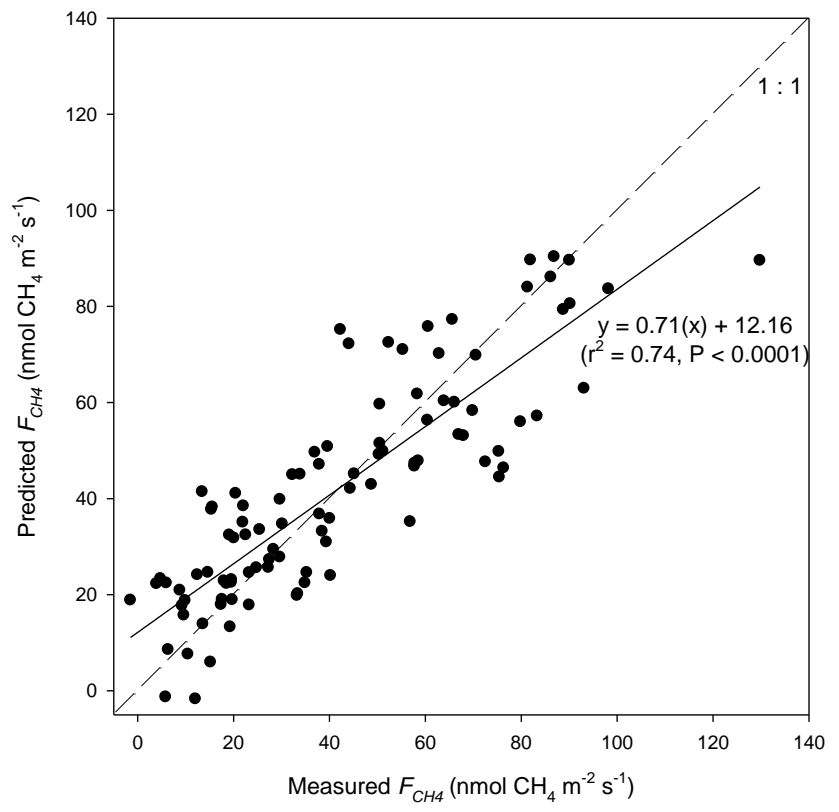

Fig. 6. Stepwise multiple linear model estimates of daily mean $F_{\mathrm{CH}_{4}}$ in relation to daily mean measured values for all measurement periods and years when water table height was below $16.61 \mathrm{~m}$ a.s.l. The model is $F_{\mathrm{CH}_{4}}=\left(-9.8 \times T_{\text {hol60 }}\right)+(279.8 \times$ water table $)+\left(1.7 \times T_{\text {air }}\right)-4572.2$.

when the water table height was above $16.61 \mathrm{~m}$ a.s.l. because no variable met the criteria to enter the analysis.

\section{Discussion}

\section{1 $\quad F_{\mathrm{CH}_{4}}$ response to spring melt and fall freeze-up}

A gradual increase in $F_{\mathrm{CH}_{4}}$ with increasing $T_{\text {air }}$ and nearsurface soil temperature ( $T_{\text {soil5 }}$ and $\left.T_{\text {sed10 }}\right)$, and lowering of the water table was observed across all springs, whereas a gradual decline in $F_{\mathrm{CH}_{4}}$ across all falls occurred with decreasing $T_{\text {air }}$, soil temperature and rising water table. We did not observe a $F_{\mathrm{CH}_{4}}$ burst in spring of 2009 or across all springs as $76 \%$ of the spring-melt data was represented by spring of 2009. However, we believe to have successfully captured two naturally occurring $30 \mathrm{~min}$ emission bursts of 20 to $34 \mathrm{nmol} \mathrm{CH}_{4} \mathrm{~m}^{-2} \mathrm{~s}^{-1}$ (compared to background emissions of $<6 \mathrm{nmol} \mathrm{CH}_{4} \mathrm{~m}^{-2} \mathrm{~s}^{-1}$ ) during fall of 2011 despite our non-continuous measurements.

These naturally occurring emission bursts in the fall of 2011 occurred during periods of low wind speed $\left(<1.4 \mathrm{~m} \mathrm{~s}^{-1}\right)$ when air temperature that was below $0^{\circ} \mathrm{C}$ formed a thin ice layer over the standing water at the fen, then went above $0{ }^{\circ} \mathrm{C}$ for several hours causing the ice to melt. Surface soil temperatures were at or above $0^{\circ} \mathrm{C}$ indicating that methane could still be produced and captured as bubbles under the ice, being released as the ice melted. A humaninduced $30 \mathrm{~min}$ emission burst of $161 \mathrm{nmol} \mathrm{CH}_{4} \mathrm{~m}^{-2} \mathrm{~s}^{-1}$ measured after breaking through thin ice in the fall of 2011 showed that physical disturbance released trapped gas bubbles to the atmosphere analogously to the naturally occurring melting of the ice, however since this disturbance was not only to the ice but to the underlying peat as well, a larger emission burst was observed than naturally occurring bursts at our fen.

Fall emission bursts from a similar fen environment underlain by continuous permafrost at Zackenberg, Greenland, have been reported by Mastepanov et al. (2008) and Tagesson et al. (2012). Mastepanov et al. (2008) used automated chambers and a closed path methane analyser to measure $\mathrm{CH}_{4}$ flux and observed several emission bursts of up to $313 \mathrm{nmol} \mathrm{CH}_{4} \mathrm{~m}^{-2} \mathrm{~s}^{-1}$ during freeze-up in early October 2008. Their fen was not inundated with water at the time of freeze-up. Mastepanov et al. (2008) described a freeze-up process whereby the active layer freezes from the top down and $\mathrm{CH}_{4}$ production continues in the thawed peat trapped between the frozen active layer and the permafrost table. The $\mathrm{CH}_{4}$ produced in the thawed peat layer gradually becomes squeezed out through frost action during freeze-up or can move through the aerenchyma of senescent vascular plants (Kim et al., 2007; Mastepanov et al., 2008). Tagesson et al. (2012) measured $F_{\mathrm{CH}_{4}}$ in 2008 and 2009 using a combination of flux gradient and eddy-covariance methods. Fall emission bursts were not observed during onset of freezing in either year, but emission bursts up to $313 \mathrm{nmol} \mathrm{CH}_{4} \mathrm{~m}^{-2} \mathrm{~s}^{-1}$ were measured after the soil was frozen during storm events in late October of 2008. Tagesson et al. (2012) suggest that methane trapped in cavities and cracks in the soil during freeze-up were released in the late October 2008 storm which created a turbulence-induced ebullition event due to changes in air pressure and ventilation in the frozen peat matrix. Because a snow cover was not present turbulent air could move through cracks and open pores in the peat. A similar late fall event was not observed in 2009 likely because the presence of snow cover protected the frozen peat matrix.

We have also observed bubbles within winter ice at the fen and ice of shallow lakes in the area, which have been reported by Duguay et al. (2002). These winter-trapped bubbles did not cause abrupt fluxes from our fen in the spring. It is hypothesized that these gases were gradually released by diffusive processes through the ice over the winter period, and therefore were not released from the bubbles as emission bursts during spring melt. We did not measure $F_{\mathrm{CH}_{4}}$ over the winter period. While previous studies have found winter $F_{\mathrm{CH}_{4}}$ to contribute up to 40 (Alm et al., 1999) and $10 \%$ (Rinne et al., 2007) of the annual $\mathrm{CH}_{4}$ budget, the measured fluxes came from fens not underlain by permafrost where over-winter soil temperatures remain $\geq 0{ }^{\circ} \mathrm{C}$ for October through April. Soil temperatures $>0{ }^{\circ} \mathrm{C}$ would be conducive to methane production and consumption by the microbial community. In contrast, our fen is within the zone of continuous permafrost, being frozen throughout the winter period (mean soil temperature $5-60 \mathrm{~cm}$ depth was $-2{ }^{\circ} \mathrm{C}$ 
and ranged from -7 to $0{ }^{\circ} \mathrm{C}$ ). Therefore we believe the overwinter fluxes should be negligible at our fen, however we acknowledge further monitoring is required to have confidence in low winter fluxes.

Other groups have observed $\mathrm{CH}_{4}$ release during spring melt in northern peatlands due to bubbles trapped in and under ice. Continuous spring-melt $F_{\mathrm{CH}_{4}}$ measurements, using eddy covariance with a tunable diode laser over a mesotrophic flark fen in Finland showed peak emission of $75 \mathrm{nmol} \mathrm{CH}_{4} \mathrm{~m}^{-2} \mathrm{~s}^{-1}$ over a six-hour period compared to a range of 12 to $50 \mathrm{nmol} \mathrm{CH}_{4} \mathrm{~m}^{-2} \mathrm{~s}^{-1}$ for the other times (Hargreaves et al., 2001). However, unlike our fen, no permafrost was present at the Finnish fen and soil was thawed from the surface to $40 \mathrm{~cm}$ depth. Wille et al. (2008) also used the eddy covariance with a tunable diode laser to determine $F_{\mathrm{CH}_{4}}$ for wet low-centred polygonal tundra in the Lena River delta, Siberia, in pre- and post-melt periods. During melt, $F_{\mathrm{CH}_{4}}$ was highly variable with multiple emission bursts with 1- to $4 \mathrm{~h}$-sustained peaks ranging from 87 to $104 \mathrm{nmol} \mathrm{CH}_{4} \mathrm{~m}^{-2} \mathrm{~s}^{-1}$ and then fluxes stabilized between -34 and $34 \mathrm{nmol} \mathrm{CH}_{4} \mathrm{~m}^{-2} \mathrm{~s}^{-1}$ after the melt. The region was within the zone of continuous permafrost, and polygon centres were thawed $>20 \mathrm{~cm}$ with standing water during the emission burst events. Tokida et al. (2007) used chambers to measure spring-melt emissions for an ombrotrophic peatland in Japan and found an emission burst as high as $439 \mathrm{nmol} \mathrm{CH}_{4} \mathrm{~m}^{-2} \mathrm{~s}^{-1}$ over a $1 \mathrm{~h}$ period. Their ombrotrophic peatland was not underlain by permafrost, and air temperatures throughout the winter and spring-melt period hovered around $0{ }^{\circ} \mathrm{C}$ resulting in diurnal freeze-thaw cycles and soil waterlogged conditions. Mastepanov et al. (2008) reported similar results as observed in our study for a graminoid fen underlain by continuous permafrost at Zackenberg Valley, northeastern Greenland. No emission bursts were observed during spring melt, rather $\mathrm{CH}_{4}$ emissions were small, but gradually increased to $35 \mathrm{nmol} \mathrm{CH}_{4} \mathrm{~m}^{-2} \mathrm{~s}^{-1}$ by midsummer..

It is suspected that sites without permafrost are more likely to be ones where $F_{\mathrm{CH}_{4}}$ emission bursts occur in the spring. Shallow frozen soil layers overlying unfrozen peat will be conducive to methane production and accumulation over winter and rapid surface thaw in spring facilitating emission bursts. This has been shown at a Finnish aapa mire (Hargreaves et al., 2001) and at an ombrotrophic peatland in Japan (Tokida et al., 2007), both of which lacked permafrost. In contrast, it is suspected that for sites with permafrost there is a greater likelihood that the spring-melt $F_{\mathrm{CH}_{4}}$ will be gradual. Active layer soil will be frozen to the permafrost table over winter which will impede methane production in winter and that surface thaw will be slower. This was observed at our fen and at the graminoid fen at Zackenberg Valley, Greenland (Mastepanov et al., 2008), both of which had continuous permafrost.

\subsection{Controls of $\mathrm{F}_{\mathrm{CH}_{4}}$}

In the current study, the univariate analysis showed $F_{\mathrm{CH}_{4}}$ was strongly associated with $T_{\text {air }}$ and all soil temperatures up to a depth of $50 \mathrm{~cm}$ during all springs, all falls, and all shoulder + growing seasons. The temperature response was significantly greater across all springs (represented mostly by spring 2009) than across all falls. Soil temperatures to a depth of $10 \mathrm{~cm}$ were found to be the most effective drivers of $F_{\mathrm{CH}_{4}}$ at our fen. The temperature response of $F_{\mathrm{CH}_{4}}$ across all springs, all falls and all shoulder + growing seasons was found to be a linear response up to a threshold. While previous studies from similar sites without permafrost (Hargreaves et al., 2001; Rinne et al., 2007; Long et al., 2009) and with discontinuous permafrost (Jackowicz-Korczynski et al., 2010) have found non-linear temperature response relationships, our fen site behaves similarly to the patterned fen underlain by continuous permafrost at Zackenberg, Greenland, (Tagesson et al., 2012) where a linear temperature response of $\mathrm{F}_{\mathrm{CH}_{4}}$ was determined with near-surface soil temperature. Most studies have reported a single $F_{\mathrm{CH}_{4}}$-soil temperature relationship during the growing season, and very few have reported on spring-melt or fall-freeze-up period $\mathrm{F}_{\mathrm{CH}_{4}}$ relationships. Our data indicate increased understanding of drivers when spring and fall relationships of $F_{\mathrm{CH}_{4}}$ with $T_{\text {air }}$ and soil temperature profiles to $50 \mathrm{~cm}$ depth are evaluated separately.

For our palsa fen underlain by continuous permafrost, the near-surface active layer is the source of production leading to spring and fall $F_{\mathrm{CH}_{4}}$ rather than release of trapped $\mathrm{CH}_{4}$ deeper in the soil. The greater response in $F_{\mathrm{CH}_{4}}$ to $T_{\text {soil5 }}$ during the spring than fall may be related to the gradual release of labile carbon from plant roots, residues and microbial biomass broken down over winter and early spring freezethaw cycles as the soil profile thaws. Edwards et al. (2006) measured microbial biomass and available soil carbon, nitrogen and phosphorus from late winter ( $T_{\text {soil }}$ from 5 to $15 \mathrm{~cm}$ depth below $-10^{\circ} \mathrm{C}$ ), through 49 days of freeze-thaw cycles (1 April-19 May), and early spring ( $T_{\text {soil }}$ from 5 to $15 \mathrm{~cm}$ above $0^{\circ} \mathrm{C}$ ) of 2005 at a nearby wet sedge meadow dominated by Carex aquatilis at Churchill, Manitoba. Results from their study indicated that microbial biomass and nutrient availability peaked during the freeze-thaw cycles and steadily declined in early spring. At our fen, the thick ice layer resulting from a high water table in fall insulated the soil and prolonged the thaw at $5 \mathrm{~cm}$ depth until mid-June and the $20 \mathrm{~cm}$ depth until mid-July. It is suspected that the peak in microbial biomass and available carbon are spread over the same time frame.

Water table position was correlated to $\mathrm{F}_{\mathrm{CH}_{4}}$ at our fen during spring of 2009, across all springs and across all shoulder + growing seasons. The highest $F_{\mathrm{CH}_{4}}$ occurred when the water table was between 2 and $13 \mathrm{~cm}$ below the mean peat surface with soil temperatures from surface to $20 \mathrm{~cm}$ depth $\geq 5^{\circ} \mathrm{C}$. However, there appears to be a wide range of controlling water table depths that are site dependent. For 
example, Zona et al. (2009) found the highest $F_{\mathrm{CH}_{4}}$ when the water table was at the peat surface and soil temperature at $10 \mathrm{~cm} \geq 4{ }^{\circ} \mathrm{C}$ at a wet sedge meadow tundra, underlain by continuous permafrost at Barrow, Alaska. Turetsky et al. (2008) used clear static chambers and showed the highest $F_{\mathrm{CH}_{4}}$ when the water table was 0 to $10 \mathrm{~cm}$ below the peat surface and soil temperature at $25 \mathrm{~cm} \geq 14{ }^{\circ} \mathrm{C}$ at a moderately rich fen near Fairbanks, Alaska, in the zone of discontinuous permafrost. Hendriks et al. (2010) used dark static chambers at a eutrophic peat meadow, not underlain by permafrost, at Horstermeer, the Netherlands, and found the highest $F_{\mathrm{CH}_{4}}$ with surface soil temperature $\geq 10^{\circ} \mathrm{C}$ and a water table 20 to $40 \mathrm{~cm}$ below the peat surface. This range indicates that understanding where $\mathrm{CH}_{4}$ is being produced in the peat profile and the transport mechanisms under varying water table positions is important.

Multivariate analysis using stepwise linear regression revealed $T_{\text {hol60 }}$ to most influence $F_{\mathrm{CH}_{4}}$ and less so water table height and $T_{\text {air }}$ when water table height was below $16.61 \mathrm{~m}$ a.s.l. Co-linearity between air and surface temperatures likely accounted for temperature at greater depths than the surface being included in the multivariate model. Further, peat surface temperatures closely pattern $T_{\text {air }}$ whereas those of water-filled hollows did not. Chamber measured fluxes at the site showed emissions from water-filled hollows to be much greater for sedge-peat surfaces and fluxes being very low from hummocks (Churchill, 2007). Zona et al. (2009) also performed multiple linear regression analysis of potential environmental drivers of $F_{\mathrm{CH}_{4}}$ and reported soil temperature at $10 \mathrm{~cm}$ depth, thaw depth and soil moisture at $20-30 \mathrm{~cm}$ together explained $94 \%$ of the variability in $F_{\mathrm{CH}_{4}}$ at a wet sedge meadow tundra near Barrow, Alaska. Wille et al. (2008) generated a multivariate model for $F_{\mathrm{CH}_{4}}$ using an exponential function incorporating soil temperature at $20 \mathrm{~cm}$ depth and wind friction velocity for a polygonal tundra in the Lena River delta, Siberia. Sachs et al. (2008) expanded the model by Wille et al. (2008) to include air pressure. These results reinforce the importance of soil temperature and water as drivers of $F_{\mathrm{CH}_{4}}$ from peatland environments underlain by continuous permafrost. The fen in the current study had a water table often near or above the mean peat surface, thus water table rather than soil moisture exerted some control over $F_{\mathrm{CH}_{4}}$.

The lack of a significant model when water table height was $>16.61 \mathrm{~m}$ a.s.l. was possibly due to a low population dataset of 30 min mean values or dampening in $F_{\mathrm{CH}_{4}}$ response to environmental conditions. $F_{\mathrm{CH}_{4}}$ was less when the water table rose above the mean sedge-peat surface of our fen. Zona et al. (2009) observed similar results for a wet sedge meadow tundra near Barrow, Alaska. In our study, a large, late summer rain $(110 \mathrm{~mm}$ in $24 \mathrm{~h}$ in 2010$)$ raised the water table $12 \mathrm{~cm}$ above the peat surface. $F_{\mathrm{CH}_{4}}$ subsequently increased as the water table dropped. Increasing $F_{\mathrm{CH}_{4}}$ with a drop in the water table position from the soil surface has also been reported for subarctic fens in northern Quebec (Wind- sor et al., 1992) and Siberia (Heyer et al., 2002), tame pasture land in southeastern Manitoba (Tenuta et al., 2010), and riparian areas in a prairie pot-hole landscape in southcentral Manitoba (Dunmola et al., 2010). It is suggested that water above a peat surface forms an aquatic environment whereby transport of $\mathrm{CH}_{4}$ through diffusion and ebullition is less efficient than transport through air (Zona et al., 2009). Heyer et al. (2002) proposed that the low solubility of $\mathrm{CH}_{4}$ causes bubble formation in near-surface soil overlain by water. As the water table lowers, release of hydrostatic pressure results in escape of bubbles through open soil pores connected to the atmosphere. We speculate that emission bursts of $\mathrm{CH}_{4}$ were not observed at our fen during spring melt partly as the result of the water table residing at or above the mean sedge-peat surface impeding the transport of $\mathrm{CH}_{4}$ to the atmosphere.

An ice barrier impeded diffusion and ebullition of $\mathrm{CH}_{4}$ further during the melt period of 2009 at our fen. Snow that had accumulated on top of the ice in winter had melted out quickly and left open water over an ice layer that extended down 10 to $30 \mathrm{~cm}$ to the peat surface. The ice thawed from the top downwards over the course of the melt period and despite $T_{\text {soil }} \geq 0{ }^{\circ} \mathrm{C}$ allowing for soil microbial activity, $\mathrm{CH}_{4}$ was trapped by this ice barrier and overlying water, slowing $\mathrm{CH}_{4}$ release to the atmosphere. Hargreaves et al. (2001) described a similar occurrence of an ice barrier layer during spring melt at their permafrost-free aapa mire in Finland, however they observed $F_{\mathrm{CH}_{4}}$ bursts which coincided with soil thawed $>40 \mathrm{~cm}$ and the occurrence of gases bubbling out from cracks in the ice barrier layer.

Across all springs, $\mathrm{NEE}_{\mathrm{MD}}$ was not significantly correlated to $F_{\mathrm{CH}_{4}}$. NEE $\mathrm{MD}$ was respiration dominated indicating that although new shoots from sedges were beginning to photosynthesize and provide some carbon in root exudates, the soil microbial communities were more effectively metabolizing over-winter-stored carbon, respiring from hummocks exposed above the water table, and emitting $\mathrm{CO}_{2}$ by diffusion through the water column from the aerobic peat-water interface. Methane was being produced in thawing anaerobic soils but in early spring the high water table inundated most of the fen. Methane could have been emitted through ebullition but we cannot be sure we captured these events during our campaigns. New sedge shoots were too small during spring melt to transfer much methane through their aerenchyma. Diffusion through the water column therefore dominated; a slow process due to methane's low solubility in water. Additionally, because the thaw layer of peat was shallow during melt, it is suggested that methane produced in the anaerobic layer was largely consumed as it moved upwards into the shallow aerobic peat-water interface. Across all falls, $\mathrm{NEE}_{\mathrm{MD}}$ had a positive correlation with $F_{\mathrm{CH}_{4}}$. At this time, the water table was mostly below the peat surface, plants had senesced and soil microbial communities were metabolizing labile carbon of roots and above-ground plant biomass, emitting both $\mathrm{CO}_{2}$ and $\mathrm{CH}_{4}$ to the atmosphere at a decreasing rate as resources depleted and temperatures declined. 


\subsection{Cumulative annual $\mathrm{CH}_{4}$ emissions}

Cumulative annual $\mathrm{CH}_{4}$ emissions for our fen ranged from 3.0 to $9.6 \mathrm{~g} \mathrm{CH}_{4} \mathrm{~m}^{-2} \mathrm{yr}^{-1}$ between the study years of 2008 to 2011. We found the mean annual flux $\pm 1 \mathrm{SE}$ over the four years ranging from $6.5 \pm 0.6$ to $7.1 \pm 1.1 \mathrm{~g} \mathrm{CH}_{4} \mathrm{~m}^{-2} \mathrm{yr}^{-1}$ when comparing the three gap-filling techniques indicating that despite out attempts to better capture diurnal variability with our modelling methods the mean annual fluxes were all within $1 \mathrm{SE}$ of each other and thus statistically similar. The cumulative annual $\mathrm{CH}_{4}$ emission results calculated in this study are within range of fluxes measured from other northern peatland sites within the zone of continuous permafrost using the eddy-covariance technique. Tagesson et al. (2012) estimated cumulative annual $\mathrm{CH}_{4}$ emissions of 8.7 to $10 \mathrm{~g} \mathrm{CH}_{4} \mathrm{~m}^{-2} \mathrm{yr}^{-1}$ for their patterned fen at Zackenberg, Greenland, in 2008 and 2009 respectively. Wille et al. (2008) estimated $3.2 \mathrm{~g} \mathrm{CH}_{4} \mathrm{~m}^{-2} \mathrm{yr}^{-1}$ for a wet polygonal tundra at the Lena River delta, Siberia, from July 2003-2004, and Hargreaves et al. (2001) estimated $5.5 \mathrm{~g} \mathrm{CH}_{4} \mathrm{~m}^{-2} \mathrm{yr}^{-1}$, modelled from data obtained during 1995, 1997 and 1998 field seasons at an aapa mire, Kaamanen, Finland. Larger cumulative annual $\mathrm{CH}_{4}$ emissions were found in zones of discontinuous or no permafrost. Jackowicz-Korczynski et al. (2010) estimated 24.5 and $29.5 \mathrm{~g} \mathrm{CH}_{4} \mathrm{~m}^{-2} \mathrm{yr}^{-1}$ from eddy-covariance measurements at a palsa mire underlain by discontinuous permafrost at Stordalen, Sweden, in 2006 and 2007 respectively, whereas Rinne et al. (2007) reported $12.6 \mathrm{~g} \mathrm{CH}_{4} \mathrm{~m}^{-2} \mathrm{yr}^{-1}$ for 2005 from a boreal minerotrophic fen with no permafrost at Siikaneva, Finland. Hendriks et al. (2007) estimated 41 and $44 \mathrm{~g} \mathrm{CH}_{4} \mathrm{~m}^{-2} \mathrm{yr}^{-1}$ from chamber measurements at a permafrost-free abandoned peat meadow at Horstermeer, the Netherlands, for 2005 and 2006 respectively. Rouse et al. (1995) used dark vented 18-L chambers at our same fen site at Churchill, estimating an average daily $F_{\mathrm{CH}_{4}}$ of 22 and $62 \mathrm{mg} \mathrm{CH}_{4} \mathrm{~m}^{-2} \mathrm{~d}^{-1}$ for specific times of year in 1989 and 1990 respectively. Our fluxes ranged from 25 to $92 \mathrm{mg} \mathrm{CH}_{4} \mathrm{~m}^{-2} \mathrm{~d}^{-1}$ for that same time period (21 June to 11 September) across all years showing good agreement.

\section{Conclusions}

Near-surface soil temperature and air temperature were the main controlling factors for $F_{\mathrm{CH}_{4}}$ from the subarctic fen in northern Manitoba explaining about $90 \%$ of the variation in fluxes during shoulder seasons. $F_{\mathrm{CH}_{4}}$ was essentially zero during frozen conditions. Emission bursts were not observed across all springs but two natural emission bursts were observed during fall of 2011. The seasonal pattern followed the temperature, and a temperature decrease coinciding with heavy rainfall inundating the fen during the growing season caused an immediate decrease in $F_{\mathrm{CH}_{4}}$ indicating that a high water table above the sedge-peat surface can overwhelm the temperature relationship. The temperature response of $F_{\mathrm{CH}_{4}}$ was significantly greater in spring than fall, providing great insight into changing seasonal responses of $\mathrm{F}_{\mathrm{CH}_{4}}$ to environmental drivers. Multivariate stepwise regression showed increasing temperature in hollows to most relate to $F_{\mathrm{CH}_{4}}$ and are less so to air temperature, and inversely to water table height. Cumulative annual $\mathrm{CH}_{4}$ emissions ranged from 3.0 to $9.6 \mathrm{~g} \mathrm{CH}_{4} \mathrm{~m}^{-2} \mathrm{yr}^{-1}$ between the years 2008 and 2011 , with mean annual $\mathrm{CH}_{4}$ emissions ranging between 6.6 and 7.1 $\mathrm{CH}_{4} \mathrm{~m}^{-2} \mathrm{yr}^{-1}$ using different gap-filling techniques. Our annual $\mathrm{CH}_{4}$ emissions are within the range of measurements at other northern fen environments underlain by continuous permafrost.

Acknowledgements. We thank staff, researchers and volunteers of the Churchill Northern Studies Centre, C. Basler, K. Davoli, J. Dunn, L. Fishback, R. Hermans, K. Jansen, S. Kuleza, C. Paddock, J. Rutter and A. Winegardner for field support, Z. Nesic (software), J. Rapai and K. Swystun for technical support. Funding was provided by the Natural Sciences and Engineering Council of Canada (NSERC) Discovery Program, the Canada Foundation for Innovation, the Canada Research Chair Program in Applied Soil Ecology and ArcticNet Network of Centres of Excellence of Canada. K. L. Hanis was supported by a NSERC Post-graduate scholarship, the Weston Award for Northern Research, the Northern Scientific Training Program, the Environment Canada Science Horizons Program and the Churchill Northern Studies Centre Northern Research Fund.

Edited by: K. Butterbach-Bahl

\section{References}

Alm, J. Saarnio, S., Nykanen, H., Silvola, J., and Martikainen, P. J.: Winter $\mathrm{CO}_{2}, \mathrm{CH}_{4}$, and $\mathrm{N}_{2} \mathrm{O}$ fluxes on some natural and drained boreal peatlands, Biogeochemistry, 44, 163-186, 1999.

Baer, D. S., Paul, J. B., Gupta, M., and O'Keefe, A.: Sensitive absorption measurements in the near-infrared region using off-axis integrated-cavity-output spectroscopy, Appl. Phys. B, 75, 261265, 2002.

Baldocchi, D., Detto, M., Sonnentag, O., Verfaillie, J., The, Y. A., Silver, W., and Kelly, N. M.: The challenges of measuring methane fluxes and concentrations over peatland pasture, Agr. Forest Meteorol., 153, 177-187, doi:10.1016/j.agrformet.2011.04.013, 2011.

Brown, R. J. E.: Permafrost in Canada; its influence on Northern development, Canadian Building Series 4, University of Toronto Press, Toronto, 1970.

Burba, G. G., McDermitt, D. K., Grelle, A., Anderson, D. J. and $\mathrm{Xu}, \mathrm{L} .:$ Addressing the influence of instrument surface heat exchange on the measurements of $\mathrm{CO}_{2}$ from open-path gas analyzers, Glob. Change Biol., 14, 1854-1876, 2008.

Churchill, J. A.: Spatial variation of soil methane and nitrous oxide emissions in subarctic environments of Churchill, Manitoba, M.Sc. Thesis, University of Manitoba, 2007.

Detto, M., Verfaillie, J., Anderson, F., Xu, L., and Baldocchi, D.: Comparing laser-based open- and closed-path gas analyzers to 
measure methane fluxes using the eddy covariance method, Agr. Forest Meteorol., 151, 1312-1324, 2011.

Duguay, C. R., Pultz, T. J., Lafleur, P. M., and Drai, D.: RADARSAT backscatter characteristics of ice growing on shallow sub-Arctic lakes, Churchill, Manitoba, Canada. Hydrol. Process., 16, 16311644, 2002.

Dunmola, A. S., Tenuta, M., Moulin, A. P., Yapa, P., and Lobb, D. A.: Pattern of greenhouse gas emission from a Prairie Pothole agricultural landscape in Manitoba, Canada, Can. J. Soil Sci., 90, 243-256, 2010.

Edwards, K. A., McCullough, J., Kershaw, G. P., and Jeffries, R. L.: Soil microbial and nutrient dynamics in a wet Arctic sedge meadow in late winter and early spring, Soil Biol. Biochem., 38, 2843-2851, 2006.

Environment Canada: National climate data and information archive, http://www.climate.weatheroffice.gc.ca, (last access: 10 November 2012), 2012.

Forster, P., Ramaswamy, V., Artaxo, P., Berntsen, T., Betts, R., Fahey, D. W., Haywood, J., Lean, J., Lowe, D. C., Myhre, G., Nganga, J., Prinn, R., Raga, G., Schulz, M., and Van Dorland, R.: Changes in Atmospheric Constituents and in Radiative Forcing, in: Climate Change 2007: The Physical Science Basis. Contribution of Working Group I to the Fourth Assessment Report of the Intergovernmental Panel on Climate Change, edited by: Solomon, S., Qin, D., Manning, M., Chen, Z., Marquis, M., Averyt, K. B., Tignor, M., and Miller, H. L., Cambridge University Press, Cambridge, UK and New York, USA, 2007.

Grondahl, L., Friborg, T., Christensen, T. R., Ekberg, A., Elberling, B., Illeris, L., Nordstrom, C., Rennermalm, A., Sigsgaard, C., and Sogaard, H.: Spatial and inter-annual variability of trace gas fluxes in a heterogeneous high-Arctic landscape, Adv. Ecol. Res., 40, 473-498, 2008.

Hargreaves, K. J., Fowler, D., Pitcairn, C. E. R., and Aurela, M.: Annual methane emission from Finnish mires estimated from eddy covariance campaign measurements, Theor. Appl. Climatol., 70, 203-213, 2001.

Hendriks, D. M. D., Dolman, A. J., van der Molen, M. K., and van Huissteden, J.: A compact and stable eddy covariance set-up for methane measurements using off-axis integrated cavity output spectroscopy, Atmos. Chem. Phys., 8, 431-443, doi:10.5194/acp-8-431-2008, 2008.

Hendriks, D. M. D., van Huissteden, J., and Dolman, A. J.: Multitechnique assessment of spatial and temporal variability of methane fluxes in a peat meadow, Agr. Forest Meteorol., 150, 757-774, 2010.

Heyer, J., Berger, U., Kuzin, I. L., and Yakovlev, O. N.: Methane emissions from different ecosystem structures of the subarctic tundra in Western Siberia during midsummer and during the thawing period, Tellus B, 54, 231-249, 2002.

Jackowicz-Korczynski, M., Christensen, T. R., Backstrand, K., Crill, P., Friborg, T., Mastepanov, M., and Strom, L.: Annual cycle of methane emission from a subarctic peatland. J. Geophys. Res. Biogeosci., 115, G02009, doi:10.1029/2008JG000913, 2010.

Joabsson, A., Christensen, T. R., and Wallen, B.:Vascular plant controls on methane emission from northern peatforming wetlands, Trends Ecol. Evol., 14, 385-388, 1999.

Kim, Y., Ueyama, M., Nakagawa, F., Tsunogai, U., Harazono, Y. and Tanaka, N.: Assessment of winter fluxes of $\mathrm{CO}_{2}$ and $\mathrm{CH}_{4}$ in boreal forest soils of central Alaska estimated by the profile method and the chamber method: a diagnosis of methane emission and implications for the regional carbon budget, Tellus B, 59, 223-233, 2007.

Kleinbaum, D. G. and Kupper, L. L.: Applied Regression Analysis and Other Multivariable Methods, Duxberry Press, North Scituate, MA, 1978.

Long, K. D., Flanagan, L. B., and Cai, T.: Diurnal and seasonal variation in methane emissions in a northern Canadian peatland measured by eddy covariance, Glob. Change Biol., 16, 2420-2435, 2009.

Los Gatos Research: Methane Analyzers: Fast - Low Power - High Precision, http://www.lgrinc.com/documents/ Methane-Analyzers-web.pdf, (last access: 25 March 2010), 2009.

Mastepanov, M., Sigsgaard, C., Dlugokencky, E. J., Houweling, S., Strom, L., Tamstorf, M. P., and Christensen, T. R.: Large tundra methane burst during onset of freezing, Nature, 456, 628-630, 2008.

McGuire, A. D., Anderson, L. G., Christensen, T. R., Dallimore, S., Guo, L., Hayes, D. J., Heimann, M., Lorenson, T. D., Macdonald, R. W., and Roulet, N.; Sensitivity of the carbon cycle in the Arctic to climate change, Ecol. Monogr., 79, 523-555, 2009.

National Wetlands Working Group: The Canadian Wetland Classification System: Second Edition, Wetland Research Centre, University of Waterloo, Ontario, 1997.

Pickett-Heaps, C. A., Jacob, D. J., Wecht, K. J., Kort, E. A., Wofsy, S. C., Diskin, G. S., Worthy, D. E. J., Kaplan, J. O., Bey, I., and Drevet, J.: Magnitude and seasonality of wetland methane emissions from the Hudson Bay Lowlands (Canada), Atmos. Chem. Phys., 11, 3773-3779, doi:10.5194/acp-11-3773-2011, 2011

Raddatz, R. L., Papakyriakou, T. N., Swystun, K. A., and Tenuta, M.: Evapotranspiration from a wetland tundra sedge fen: surface resistance of peat for land-surface schemes, Agr. Forest Meteorol., 149, 851-861, 2009.

Rinne, J., Riutta, T., Pihlatie, M., Aurela, M., Haapanala, S., Tuovinen, J. P., Tuittila, E. S., and Vesala, T.: Annual cycle of methane emission from a boreal fen measured by the eddy covariance technique, Tellus B, 59, 449-457, 2007.

Rouse, W. R., Holland, S., and Moore, T. R.: Variability in methane emissions from wetlands at northern treeline near Churchill, Manitoba, Arctic Alpine Res., 27, 146-156, 1995.

Rouse, W. R., Bello, R. L., D’Souza, A., Griffis, T. J., and Lafleur, P. M.: The annual carbon budget for fen and forest in a wetland at Arctic treeline, Arctic, 55, 229-237, 2002.

Sachs, T. Wille, C., Boike, J., and Kutzbach, L.: Environmental controls on ecosystem-scale $\mathrm{CH}_{4}$ emission from polygonal tundra in the Lena River Delta, Siberia, J. Geophys. Res.-Biogeo., 113, G00A03, doi:10.1029/2007JG000505, 2008.

Schimel, J. P.: Plant transport and methane production as controls on methane flux from Arctic wet meadow, Biogeochemistry, 28, 183-200, 1995.

Shindell, D. T., Galuvegi, G., Koch, D. M., Schmidt, G. A., Unger, N., and Bauer, S. E.: Improved attribution of climate forcing to emissions, Science, 326, 716-718, 2009.

Tagesson, T., Molder, M., Mastepanov, M., Sigsgaard, C., Tamstorf, M. P., Lund, M., Falk, J. M., Lindroth, A., Christensen, T. R., and Strom, L.: Land-atmosphere exchange of methane from soil thawing to soil freezing in a high-Arctic wet tundra ecosys- 
tem, Glob. Change Biol., 18, 1928-1940, doi:10.1111/j.13652486.2012.02647.x, 2012.

Tanner, C. B. and Thurtell, G. W.: Sensible heat flux measurements with a yaw sphere and thermometer: anemoclinometer measurements of Reynolds stress and heat transport in the atmospheric surface layer, TR Ecom 66-G22-F, http://www.dtic.mil/cgi-bin/GetTRDoc?Location=U2\&doc= GetTRDoc.pdf\&AD=AD0689487, Dept. Soil Science, Univ. Wisconsin, Madison, WI, 1969.

Tarnocai, C., Canadell, J. G., Schuur, E. A. G., Kuhry, P., Mazhitova, G., and Zimov, S.: Soil organic carbon pools in the northern circumpolar permafrost region, Global Biogeochem. Cy., 23, GB2023, doi:10.1029/2008GB003327, 2009.

Tenuta, M., Mkhabela, M., Tremorin, D., Coppi, L., Phipps, G., Flaten, D., and Ominski, K.: Nitrous oxide and methane emission from a coarse-textured grassland soil receiving hog slurry, Agr. Ecosys. Environ., 138, 35-43, 2010.

Tokida, T., Mizoguchi, M., Miyazaki, T., Kagemoto, A., Nagata, O., and Hatano, R.: Episodic release of methane bubbles from peatland during spring thaw, Chemosphere, 70, 165-171, 2007.

Turetsky, M. R., Treat, C. C., Waldrop, M. P., Waddington, J. M., Harden, J. W., and McGuire, A. D.: Short-term response of methane fluxes and methanogen activity to water table and soil warming manipulations in an Alaskan peatland, J. Geophys. Res.-Biogeosci., 113, G00A10, doi:10.1029/2007JG000496, 2008.
Updegraff, K., Bridgham, S. D., Pastor, J., Weishampel, P., and Harth, $\mathrm{C} .:$ Response of $\mathrm{CO}_{2}$ and $\mathrm{CH}_{4}$ emissions from peatlands to warming and water table manipulations, Ecol. Appl., 11, 311326, 2001.

Verville, J. H., Hobbie, S. E., Chapin, F. S., and Hooper, D. U.: Response of tundra $\mathrm{CH}_{4}$ and $\mathrm{CO}_{2}$ flux to manipulation of temperature and vegetation, Biogeochemistry, 41, 215-235, 1998.

Webb, E. K., Pearman, G., and Leuning, R.: Correction of flux measurements for density effects due to heat and water vapour transfer, Q. J. Roy. Meteorol. Soc., 106, 85-100, 1980.

Wille, C., Kutzbach, L., Sachs, T., Wagner, D., and Pfeiffer, E. M.: Methane emission from Siberian Arctic polygonal tundra: eddy covariance measurements and modeling, Glob. Change Biol., 14, 1395-1408, 2008.

Windsor, J., Moore, T. R., and Roulet, N. T.: Episodic fluxes of methane from subarctic fens, Can. J. Soil Sci., 72, 441-452, 1992.

Zona, D., Oechel, W. C., Kochendorfer, J., Paw, U. K. T., Salyuk, A. N., Olivas, P. C., Oberbauer, S. F., and Lipson, D. A.: Methane fluxes during the initiation of a large-scale water table manipulation experiment in the Alaskan Arctic tundra, Global Biogeochem. Cy., 23, GB2013, doi:10.1029/2009GB003487, 2009. 